\title{
Adding Colors to the Chameleon: Why the Supreme Court Should Have Adopted a New Compelling Governmental Interest Test for Race- Preference Student Assignment Plans
}

\section{Leslie Yalof Garfield ${ }^{*}$}

\section{INTRODUCTION}

When the Supreme Court ordered the City of Topeka to desegregate its schools in $1954,{ }^{1}$ it failed to consider the long-range implications of its mandate. School districts across the country responded to the Court's order by adopting race-preference school assignment plans. The plans designated the particular public elementary or secondary school a student should attend in an attempt to integrate public school classrooms.

Once these plans successfully achieved their goal of desegregating classrooms, the question became whether the continuation of the very programs that helped achieve that goal remained legal. In other words, could it now be that "“[w] hat's constitutionally required one day gets constitutionally prohibited the next day?", This very issue was recently under consideration by the Supreme Court. ${ }^{3}$

In June 2007, the Court decided Parents Involved in Community Schools v. Seattle School District No. 1 and Meredith v. Jefferson County Board of Education. ${ }^{4}$ Petitioners in both cases, which the Court decided together, challenged long-standing school assignment plans that allowed limited consideration for racial preference when assigning students in grades $\mathrm{K}-12$ to a particular school. ${ }^{5}$ The genesis of the Jefferson County

Leslie Yalof Garfield, Professor of Law, Pace Law School. The author would like to express deep gratitude to Alison Kronstadt and Megan McDonald for their wonderful research assistance, and David Stuart for his unselfish willingness to provide outstanding research and sound editorial assistance on a moment's notice. Finally, I would like to thank Professor Bennett Gershman for his continued support, guidance, and creative thought.

1. Brown v. Bd. of Educ., 347 U.S. 483 (1954).

2. Adam Liptak, Brown v. Board of Education, Second Round, N.Y. TIMES, Dec. 10, 2006, § 4, at 3 (quoting Justice Ginsburg's comments during oral arguments).

3. See Parents Involved in Cmty. Sch. v. Seattle Sch. Dist. No. 1, 127 S. Ct. 2738 (2007).

4. Id.

5. McFarland v. Jefferson County Pub. Sch., 330 F. Supp. 2d 834, 836 (W.D. Ky. 2004), aff'd, 
Board of Education's plan (the "Jefferson County BOE Plan") was a court-ordered desegregation. ${ }^{6}$ When petitioners challenged the plan in 2002, the evidence showed that the schools were in fact successfully integrated. ${ }^{7} \quad$ Petitioners argued the plan was no longer permissible because there were no present effects of past discrimination. ${ }^{8}$ The Seattle School Board adopted its plan (the "Seattle Plan") because assigning students to schools based on their residential neighborhood resulted in de facto segregation. ${ }^{9}$ Opponents challenged the Seattle Plan under the Equal Protection Clause, arguing it unfairly favored one group based on race. ${ }^{10}$

During the December 2006 hearings before the Court, Justice Breyer articulated the grave danger of striking down the Jefferson County BOE Plan when he asked: "How could the Constitution the day that that decree is removed tell the school board it cannot make effort any more, it can't do what it's been doing, and we'll send the children back to their black schools and their white schools?"11 Yet, at the time of the hearings, the law supported doing just that, since the Court had previously limited the permissible use of race to remedying present effects of past discrimination and assuring diverse viewpoints in institutions of higher education. ${ }^{12}$

As a general matter, the Court can only uphold a race-preference plan challenged on equal protection grounds if the plan survives strict scrutiny. ${ }^{13}$ A plan will survive if the defending group can show a compelling governmental interest in achieving the plan's goals. ${ }^{14}$ In

416 F.3d 513 (6th Cir. 2005), cert. granted sub nom. Meredith v. Jefferson County Bd. of Educ., 127 S. Ct. 2351 (2006), rev'd sub nom. Parents Involved in Cmty. Sch. v. Seattle Sch. Dist. No. 1, 127 S. Ct. 2738 (2007) [hereinafter McFarland I]; Parents Involved in Cmty. Sch. v. Seattle Sch. Dist. No 1, 137 F. Supp. 2d 1224, 1239-41 (W.D. Wash. 2001), rev'd, 285 F.3d 1236 (9th Cir. 2002), certifying questions to Washington Supreme Court, 294 F.3d 1085 (9th Cir. 2002), certifying questions answered, 72 P.3d 151 (Wash. 2003), rev'd, 377 F.3d 949 (9th Cir. 2004), aff'd en banc, 426 F.3d 1162 (9th Cir. 2005), rev'd 127 S. Ct. 2738 (2007) [hereinafter Parents Involved I].

6. McFarland I, 330 F. Supp. 2d at 836 . The plan was developed in response to a 1975 federal court order. The school chose to continue the program of integration after the end of the court mandate. Id.

7. See id. at 841-42 (noting court dissolution of original desegregation decree).

8. See id. at 835 .

9. See Parents Involved in Cmty. Sch. v. Seattle Sch. Dist., No. 1, 426 F.3d 1162, 1167 (9th Cir. 2005) (en banc), rev'd, 127 S. Ct. 2738 (2007), vacated, 498 F.3d 1059 (2007) [hereinafter Parents Involved VII].

10. Id. at 1171 .

11. Transcript of Oral Argument at 12, Meredith v. Jefferson County Bd. of Educ., 127 S. Ct. 2738 (2007) (No. 05-915).

12. See infra Part II.

13. See infra note 19.

14. See infra note 20 . 
Grutter v. Bollinger, Justice O'Connor wrote that "[c]ontext matters" in evaluating a state's compelling governmental interest in using racepreference programs. ${ }^{15}$ Under Grutter, therefore, identifying a new context justifies defining a new compelling governmental interest. ${ }^{16}$ Five Justices in the Parents Involved Court invalidated both the Jefferson County BOE Plan and the Seattle Plan on equal protection grounds. ${ }^{17}$ Four of those Justices refused to extend the compelling governmental interest in viewpoint diversity to public grammar schools. ${ }^{18}$ The Court's decision will prove fatal to school assignment plans across the country, as many school boards will be unable to produce evidence that their existing programs were necessary to remedy present effects of past discrimination in a court of law.

This Article takes a retrospective look at the legal environment leading up to the Court's 2007 decision in Parents Involved and argues that the Court should have articulated a third compelling governmental interest upholding race-preference plans or programs where the programs' abolishment would threaten a return to the de facto segregation that the plans originally sought to cure. Part II of this Article will define the historical evolution of the strict scrutiny test and the Court's willingness to allow the context of a particular race-preference issue to drive the definition of a compelling governmental interest. Part III will consider district and appellate court responses to the applicability of the Court's two articulated compelling governmental interests, particularly in cases considering challenges to race-preference student assignment plans. Finally, Part IV will argue that the Court should have created a new compelling governmental interest for evaluation of racepreference student assignment plans, since invalidation of these school board plans may cause a return to the social conditions that originally necessitated their creation.

\section{THE SUPREME COURT'S APPLICATION OF THE STRICT SCRUTINY TEST}

The Supreme Court has long held that any race-preference policy must be subject to the strictest scrutiny. ${ }^{19}$ A policy passes the strict

5. 539 U.S. 306,327 (2005).

16. See id.

17. See infra notes $188-96$ and accompanying text.

18. See Parents Involved in Cmty. Sch. v. Seattle Sch. Dist. No. 1, 127 S. Ct. 2738, 2753-54 (2007).

19. See Adarand Constructors, Inc. v. Pena, 515 U.S. 200, 216 (1995); City of Richmond v. 
scrutiny test if the governmental body defending the policy can demonstrate that there is a compelling governmental interest in using the policy and that the policy is narrowly tailored to meet that interest. ${ }^{20}$ The Court first used the strict scrutiny test to evaluate a race-preference policy in Regents of the University of California v. Bakke. ${ }^{21}$

\section{A. Regents of the University of California v. Bakke: Viewpoint Diversity as a Compelling Governmental Interest}

In Bakke, the Court considered an equal protection challenge to the University of California at Davis Medical School's ("Davis") 1973 admissions policy, which the school adopted in an effort to diversify its entering class. ${ }^{22}$ Allen Bakke, a white male who had been rejected from admission to the school, claimed that the policy violated the Equal Protection Clause, ${ }^{23}$ the California Constitution, ${ }^{24}$ and Title VI of the Civil Rights Act of 1964 ("Title VI") ${ }^{25}$ because the policy set aside a specific number of seats for students in identified minority groups. ${ }^{26}$ Petitioner, the Regents of the University of California, argued that the Davis program should not be subject to the strict scrutiny test for two reasons. First, Petitioner argued that white males are not members of a discrete and insular minority group, and as such do not require extraordinary protection. ${ }^{27}$ Secondly, petitioner pointed out that in instances where race was a factor, such as school and employment desegregation, the Court did not always subject the challenged program or policy to strict scrutiny. ${ }^{28}$ The Court concluded that, because the

J.A. Croson Co., 488 U.S. 469, 493-94 (1989); United States v. Paradise, 480 U.S. 149, 166-67 (1987); Wygant v. Jackson Bd. of Educ., 476 U.S. 267, 273 (1986).

20. Grutter, 539 U.S. at 326.

21. 438 U.S. 265 (1978).

22. Id. at 265 .

23. U.S. CONST. amend. XIV, $\S 1$ ("No State shall make or enforce any law which shall abridge the privileges or immunities of citizens of the United States; nor shall any State deprive any person of life, liberty, or property, without due process of law; nor deny to any person within its jurisdiction the equal protection of the laws.").

24. CAL. CONST. art. I, § 7(b) ("A citizen or class of citizens may not be granted privileges or immunities not granted on the same terms to all citizens. Privileges or immunities granted by the Legislature may be altered or revoked.").

25. 42 U.S.C. $\S 2000 d$ (2000) ("No person in the United States shall, on the ground of race, color, or national origin, be excluded from participation in, be denied the benefits of, or be subjected to discrimination under any program or activity receiving Federal financial assistance.").

26. Bakke, 438 U.S. at 265.

27. Id. at 290 .

28. Id. at 300. The Davis special admissions program involved the use of an explicit racial classification never before countenanced by this Court. It tells applicants who are not Negro, Asian, or Chicano that they are totally excluded from a specific 
Davis program involved the use of an explicit racial classification, the program's preferential treatment of certain minority groups potentially disregarded individual rights as guaranteed by the Fourteenth Amendment. ${ }^{29}$ Justice Powell wrote that when a program touches upon "an individual's race or ethnic background, he is entitled to a judicial determination that the burden he is asked to bear . . is precisely tailored to serve a compelling governmental interest."

The Court's language became the embodiment of the strict scrutiny test. After Bakke, any program or policy that had a direct impact on an individual because of race, regardless of whether that race was a minority class, would be subject to strict scrutiny - the most exacting standard of review. To survive strict scrutiny, the party promoting the challenged race-preference program would have to demonstrate that there was a compelling governmental interest in the program and that the program was narrowly tailored to meet that interest. ${ }^{31}$

Using this standard, the Court struck down the Davis policy. ${ }^{32}$ Justice Powell, writing for the majority, concluded that the Davis program violated both Title VI and the Equal Protection Clause. ${ }^{33}$ Justice Powell found that there was a compelling governmental interest in attaining a diverse student body, ${ }^{34}$ and thus that the Constitution does not bar admissions policies from introducing race as a factor in the selection process. Nevertheless, Justice Powell found that the program was not narrowly tailored and that "[p]referring members of any one group for no reason other than race or ethnic origin is discrimination for its own sake." ${ }^{35}$ The Davis admissions policy, which set aside a specific number of seats for students in identified minority groups, unfairly

percentage of the seats in an entering class. No matter how strong their qualifications, quantitative and extracurricular, including their own potential for contribution to educational diversity, they are never afforded the chance to compete with applicants from the preferred groups for the special admissions seats. At the same time, the preferred applicants have the opportunity to compete for every seat in the class.

Id. at 319-20.

29. Id. at 320 (citing Shelley v. Kraemer, 334 U.S. 1, 22 (1948)).

30. Id. at 299 (citing Shelley, 334 U.S. at 22; Missouri ex rel. Gaines v. Canada, 305 U.S. 337 , 351 (1938)). "In order to justify the use of a suspect classification, a State must show that its purpose or interest is both constitutionally permissible and substantial, and that its use of the classification is 'necessary... to the accomplishment' of its purpose or the safeguarding of its interest." In re Griffiths, 413 U.S. 717, 721-22 (1973) (footnotes omitted) (quoting McLaughlin v. Florida, 379 U.S. 184, 196 (1964)).

31. Bakke, 438 U.S. at 299.

32. Id. at 320

33. Id. at 270-71.

34. Id. at 311-12.

35. Id. at 307,315 . 
benefited the interest of a victimized group at the expense of other innocent individuals and, therefore, violated the Equal Protection Clause. $^{36}$

Justice Powell's edict would come to be called "viewpoint diversity." 37 After Bakke, the Court recognized that programs designed to achieve diversity at the graduate school level served a compelling governmental interest. ${ }^{38}$ Evidence that a race-preference admissions program was designed to create viewpoint diversity was sufficient to support a court's upholding the race-preference admissions program. Indeed, a majority of the Bakke Court recognized the university's constitutional right to select students who would best contribute to the " "robust exchange of ideas." 39 "Ethnic diversity, however, is only one element in a range of factors a university properly may consider in attaining the goal of a heterogeneous student body." 40

\section{B. Race-Preference Policies in the Workplace: Ameliorating Present Effects of Past Discrimination as a Compelling Governmental Interest}

Almost a decade after Bakke, the Court began reviewing a series of challenges to race-preference policies in the workplace. ${ }^{41}$ These cases, read together, articulated clear guidelines for the application of the strict scrutiny test ${ }^{42}$ and confirmed that a reviewing court could only uphold an

\section{Id. at 307 .}

37. Judge Friedman, writing for the District Court for the Eastern District of Michigan in the context of race-preference programs, first identified the term "viewpoint diversity." Viewpoint diversity means "a diversity of viewpoints, experiences, interests, perspectives, and backgrounds which creates an atmosphere most conducive to learning." Grutter v. Bollinger, 137 F. Supp. 2d 821, 849 (E.D. Mich. 2001), rev'd, 288 F.3d 732 (6th Cir. 2002), aff'd, 539 U.S. 306 (2003).

38. Grutter v. Bollinger, 539 U.S. 306, 325 (2003). (1967)).

39. Bakke, 438 U.S. at 312-13 (quoting Keyishian v. Bd. of Regents, 385 U.S. 589, 603

40. Id. at 314 .

41. See, e.g., Adarand Constructors, Inc. v. Pena, 515 U.S. 200 (1995) (reviewing federal agency contract clause providing financial incentive to hire certified disadvantaged businesses); City of Richmond v. J.A. Croson Co., 488 U.S. 469 (1989) (reviewing city policy requiring that at least thirty percent of any city construction contract be subcontracted to "Minority Business Enterprises"); United States v. Paradise, 480 U.S. 149 (1987) (reviewing district court order requiring that fifty percent of promotions to certain ranks within the Alabama Department of Public Safety be given to qualified black candidates); Wygant v. Jackson Bd. of Educ., 476 U.S. 267 (1986) (reviewing provision in teacher contract which resulted in non-minority teachers with greater seniority being laid off before minority teachers with lesser seniority).

42. See, e.g., Paradise, 480 U.S. at 171 (citing Local 28 of the Sheet Metal Workers' Int'l Ass'n v. EEOC, 478 U.S. 421, 481 (1986)) (listing several factors to consider in determining the appropriateness of race-conscious guidelines, "including the necessity for the relief and the efficacy of alternative remedies; the flexibility and duration of the relief, including the availability of waiver 
affirmative action program or policy in the workplace if it was aimed at ameliorating present effects of past discrimination and if the program was narrowly tailored to meet that goal. ${ }^{43}$

In the first post-Bakke decision to consider the constitutionality of affirmative action policies, Justice Powell, again writing for the plurality, took the opportunity to reaffirm the requirement that these programs pass the strict scrutiny test before a court may pronounce them constitutional. ${ }^{44}$ In Wygant v. Jackson Board of Education, the Court considered a collective bargaining agreement between the Jackson Board of Education and a teachers' union that prevented the percentage of minorities laid off from exceeding the percentage of minorities employed at the time. ${ }^{45}$ In this instance, the Court found that the government's interest in reversing the trend of societal discrimination was not sufficient to support a compelling governmental interest. ${ }^{46}$ The Court struck down the policy for violating the Fourteenth Amendment, holding that "some showing of prior discrimination by the governmental unit involved" is required before limited use of racial classifications is allowed in order to remedy discrimination. ${ }^{47}$

In United States v. Paradise, the next equal protection challenge to a race-preference policy, the Court took the opportunity to reaffirm its position on what evidence would support a compelling governmental interest. ${ }^{48}$ The Court considered the constitutionality of a one-black-toone-white promotion plan that the Alabama Department of Public Safety adopted pursuant to a district court order, ${ }^{49}$ as modified by later consent decrees. ${ }^{50}$ Relying on Wygant, Justice Brennan wrote that a court may find a compelling governmental interest where the entity promoting the policy can demonstrate that it is designed to remedy present effects of past discrimination. ${ }^{51}$

provisions; the relationship of the numerical goals to the relevant labor market; and the impact of the relief on the rights of third parties.").

43. See Croson, 488 U.S. at 493-94 (holding that courts must apply the strict scrutiny test to judicial review of state and local government affirmative action programs); see also Adarand, 515 U.S. at 227 (mandating the use of the strict scrutiny test for federal race-preference programs). See generally Leslie Yalof Garfield, Squaring Affirmative Action Admissions Policies with Federal Judicial Guidelines: A Model for the Twenty-First Century, 22 J.C. \& U.L. 895 (1996).

44. Wygant, 476 U.S. at 273-74.

45. Id. at $270-71$.

46. Id. at 274 .

47. $I d$.

48. 480 U.S. 149 (1987).

49. Id. at $154-55$.

50. Id. at $157-60$.

51. Id. at 166 ("It is now well established that government bodies, including courts, may constitutionally employ racial classifications essential to remedy unlawful treatment of racial or 
Following Paradise, the Court was faced with several more challenges to affirmative action policies aimed at eradicating discrimination in the workplace. In City of Richmond v. J.A. Croson Co., the Court considered a municipal plan that required a primary city contractor to award thirty percent of the amount of its contract to Minority Business Enterprises ("MBEs"), defined as subcontractor businesses owned by members of certain minority groups. ${ }^{52}$ In Adarand Constructors, Inc. v. Pena, the Court extended the strict scrutiny standard of review to federal race-preference programs. ${ }^{53}$ Both Adarand and Croson confirmed that eradicating present effects of past discrimination is a compelling governmental interest.

\section{Context Matters When Defining What Constitutes a Compelling Governmental Interest}

In 2003, the Court revisited the constitutionality of race-preference programs aimed at achieving diversity in the classroom for the first time in twenty-five years. Grutter v. Bollinger ${ }^{54}$ and its companion case Gratz v. Bollinger ${ }^{55}$ considered the constitutionality of affirmative action admissions programs at the University of Michigan School of Law ("Law School") and the University of Michigan College of Literature, Science, and Arts ("LSA"). The Supreme Court concluded that the particulars of the strict scrutiny test applied in Wygant and Paradise were ill-suited for evaluating the programs challenged in Grutter and Gratz.

Plaintiffs in Gratz $^{56}$ challenged LSA's admissions policy under $\S \S$ 1981 and 1983 of the Civil Rights Act, ${ }^{57}$ and the Equal Protection Clause of the Fourteenth Amendment, ${ }^{58}$ alleging that LSA improperly used race as a factor in determining admissions. Under one variation of the admissions policy, the school used a 150-point scale to rate applicants. Applicants were assigned points based on several factors, including high

ethnic groups subject to discrimination.").

52. 488 U.S. $469,477-78$ (1989).

53. 515 U.S. 200, 235-37 (1995); see also Leslie Yalof Garfield, Hopwood v. Texas: Strict in Theory or Fatal in Fact, 34 SAN DIEGO L. REV. 497, 516 n.95 (1997) (discussing Adarand).

54. 539 U.S. 306 (2003).

55. 539 U.S. 244 (2003).

56. Jennifer Gratz and Patrick Hamacher "both applied for admission to the University of Michigan's ... College of Literature, Science, and the Arts (LSA) as residents of the State of Michigan. Both petitioners [were] Caucasian." Gratz, 539 U.S. at 251. Both were told that they were qualified, but not sufficiently qualified to be admitted for "first review." Id. Both were later denied admission and attended other universities. Id. at 251 .

57. 42 U.S.C. $\S \S 1981,1983$ (2000).

58. Gratz, 539 U.S. at 252. 
school grade point average, standardized test scores, high school curriculum, alumni relationship, personal essay, demonstrated leadership qualities, and underrepresented racial or ethnic background. Students from an under-represented racial or ethnic background were automatically assigned twenty points, a significant advantage over students not from an under-represented racial or ethnic background. ${ }^{59}$ The district court upheld the program and plaintiffs appealed to the Supreme Court. ${ }^{60}$

The plaintiff in Grutter challenged the Law School's admissions policy that called for enrollment of a "critical mass of minority students" as a means of ensuring a diverse student body. ${ }^{61}$ Under the written policy, those reviewing applications for admission were encouraged to consider factors including recommendations, quality of one's undergraduate institution, essays, course selection, and whether the applicant had a perspective or experience that would contribute to a diverse student body. ${ }^{62}$ The district court struck down the Law School policy finding that it did not survive the strict scrutiny test. ${ }^{63}$ The Sixth Circuit reversed. ${ }^{64}$

The Supreme Court reviewed each policy under the strict scrutiny test, because the plaintiffs in each case challenged the respective affirmative action admissions policies as violative of Equal Protection Clause. ${ }^{65}$ In both cases, the Court swiftly accepted as binding Justice Powell's majority opinion in Bakke, finding a compelling governmental interest in achieving a diverse entering class. ${ }^{66}$

The Court upheld the Law School's affirmative action policy, finding that its admissions program did not violate the Equal Protection Clause. ${ }^{67}$ The majority reaffirmed Justice Powell's conclusion in Bakke that achieving diversity in education is a compelling governmental interest. ${ }^{68}$ It then turned its attention to whether the policy was narrowly

59. Id. at 255; see also Leslie Yalof Garfield, Back to Bakke: Defining the Strict Scrutiny Test for Affirmative Action Policies Aimed at Achieving Diversity in the Classroom, 83 Neb. L. Rev. 631, 655-56 (2005) (discussing the LSA policy).

60. See Gratz, 539 U.S. at 259-60.

61. Grutter v. Bollinger, 539 U.S. 306, 315-17 (2003).

62. Id. at 315 .

63. Id. at 321

64. Id.

65. Gratz, 539 U.S. at 270; Grutter, 539 U.S. at 326.

66. See Gratz, 539 U.S. at 270-71; Grutter, 539 U.S. at 325.

67. Grutter, 539 U.S. at 343.

68. Id. at 328. "[A]ttaining a diverse student body is at the heart of the Law School's proper institutional mission, and ... 'good faith' on the part of a university is 'presumed' absent 'a showing to the contrary." Id. at 329 (quoting Regents of the Univ. of Cal. v. Bakke, 438 U.S. 265, 318-19 
tailored to meet that interest. The majority acknowledged the need for a modified version of the Paradise test, holding that the "inquiry must be calibrated to fit the distinct issues raised by the use of race to achieve student body diversity in public higher education." ${ }^{69}$ Consequently, the Court found that it was perfectly appropriate for courts to fashion a unique narrowly tailored prong of the strict scrutiny test in light of the particular context of the challenged program. ${ }^{70}$ In this instance, the Court held, in order to pass the narrowly tailored test, the party defending an affirmative action admissions program need only demonstrate that the program was flexible and non-mechanical, and limited in its duration. ${ }^{71}$

In contrast, the Court struck down LSA's admissions policy because it was not narrowly tailored to meet the compelling governmental interest of achieving a diverse student body. ${ }^{72}$ LSA's policy went beyond the spirit of Justice Powell's edict that race can be considered as a factor in admissions, since it failed to allow for interpretation of "individual qualities or experience not dependent upon race but sometimes associated with it." ${ }^{73}$ Therefore, the program was not narrowly drawn in a constitutionally permissible way. ${ }^{74}$

Justice O'Connor's early pronouncement that "[c]ontext matters" when reviewing race-preference governmental action under the Equal Protection Clause ${ }^{75}$ set the stage for distinguishing the Court's findings in these decisions from those in Wygant, Adarand, and the like. "Context matters," she wrote, because "[n]ot every decision influenced by race is equally objectionable, and strict scrutiny is designed to provide a framework for carefully examining the importance and the sincerity of the reasons advanced by the governmental decision-maker for the use of race in that particular context." ${ }^{, 76}$ The Court's decision to uphold the Law School's policy not only identified for the first time a permissible affirmative action policy in the context of education, but it also gave the

(1978)). “[S]kills needed in today's increasingly global marketplace can only be developed through exposure to widely diverse people, cultures, ideas, and viewpoints." Id. at 330.

69. Id. at 333-34.

70. Id.

71. Id.

72. Gratz v. Bollinger, 539 U.S. 244, 268-69 (2003).

73. Id. at 272-73 (emphasis removed) (quoting Bakke, 438 U.S. at 324). See generally Leslie Yalof Garfield, The Cost of Good Intentions: Why the Supreme Court's Decision Upholding Affirmative Action Admission Programs Is Detrimental to the Cause, 27 PACE L. REV. 15 (2006) (considering "the stringent requirements of the Grutter and Gratz Decisions").

74. Gratz, 539 U.S. at 275.

75. Grutter, 539 U.S. at 327; see also Jeramy R. Green, Affirmative Action: Challenges and Opportunities, 2004 BYU EDUC. \& L.J. 139, 149-51 (2004) (describing empirical studies investigating the importance of diversity in higher education).

76. Grutter, 539 U.S. at 327. 
lower courts license to design different "frameworks" for evaluating affirmative action policies depending on the need for a particular program. Consequently, the Court can evaluate a race-preference action against a test suited to the particular interest sought to be accomplished by a governmental entity.

In 2005, in Johnson v. California, ${ }^{77}$ the Court concluded that the context in which a policy is applied dictates an appropriate definition of strict scrutiny. ${ }^{78}$ The Johnson Court considered whether the strict scrutiny test applies to an Equal Protection challenge to the California Department of Correction's ("CDC") "unwritten policy of racially segregating prisoners in double cells in reception centers for up to 60 days each time they enter a new correctional facility." ${ }^{, 79}$ Without reaching the merits, ${ }^{80}$ the Court clearly stated that "all racial classifications [imposed by government]... must be analyzed by a reviewing court under strict scrutiny,", even when their effects equally burden or benefit the members of the races involved. ${ }^{81}$ The Court rejected CDC's argument that it should be exempt from a strict scrutiny analysis because prisoners were equally segregated. ${ }^{82}$ Although the Court did not define what evidence might justify a compelling governmental interest in dividing inmates by race, or consider whether CDC's program was narrowly tailored, it held that strict scrutiny applies in every context, "even for so-called 'benign' racial classifications, such as race-conscious university admissions policies." 83 The Court's language suggests that a different strict scrutiny test might be appropriate for evaluating a race-preference policy in the context of prisoners' rights.

Justice Ginsburg wrote a concurrence joined by Justices Souter and Breyer. Justice Ginsburg disagreed with the Court that strict scrutiny properly applies to any and all racial classifications. ${ }^{84}$ Citing her opinions in Grutter and Gratz, Justice Ginsburg held that "the same standard of review ought not to control judicial inspection of every

77. 543 U.S. 499 (2005).

78. See id. at 515 ("[C]ircumstances can be considered in applying strict scrutiny, which is designed to take relevant differences into account.").

79. Id. at 502 .

80. "We do not decide whether the CDC's policy violates the Equal Protection Clause." Id. at 515.

81. Id. at 505-06 (alteration in original) (quoting Adarand Constructors, Inc. v. Pena, 515 U.S. 200, $227(1995))$.

82. $I d$. at 506 .

83. Id. at 505 (citing Grutter v. Bollinger, 539 U.S. 306, 326 (2003)).

84. Id. at 516 (Ginsburg, J., concurring). 
official race classification." ${ }^{85}$ In her opinion, actions aimed at ameliorating present effects of past discrimination ("“[a]ctions designed to burden groups long denied full citizenship stature"') should be subject to a more exacting scrutiny than those measures that are adopted as a result of the "aftereffects" of discrimination. ${ }^{86}$ Under this analysis, context dictates not only a governmental entity's justification for the compelling governmental interest, it dictates whether the strict scrutiny test is applicable at all.

As a general matter, courts considering equal protection challenges to race-preference policies have found compelling governmental interests in only two instances: (1) where programs are aimed at ameliorating present effects of past discrimination in the workplace; and (2) where programs are aimed at creating a diverse learning environment in the classroom. The Johnson opinion, particularly Justice Ginsburg's finding that "the same standard of review ought not to control judicial inspection of every official race classification," ${ }^{87}$ suggested it is permissible to broaden the definition of what constitutes a compelling governmental interest in other contexts. As a result, the body of case law considering equal protection challenges to race-preference programs left room for lower courts to conclude that the present strict scrutiny test could be further reconstituted. As lower courts began to consider challenges to programs beyond those created for the workplace or for higher education, Justice O'Connor's edict that "context matters" left open a Pandora's box allowing courts to define compelling governmental interests that best suited their desired results.

\section{Appellate Court Evaluations of Race-Preference Policies}

The Court has neatly divided treatment of race-preference policies into two categories. ${ }^{88}$ When evaluating affirmative action policies in the workplace, the Court has applied the Paradise test. ${ }^{89}$ When evaluating affirmative action for higher education, the Court has applied the Grutter test. $^{90}$ The Johnson Court's holding, however, suggests that when the

\footnotetext{
85. Id.

86. See id. (quoting Gratz v. Bollinger, 539 U.S. 244, 301 (2003) (Ginsburg, J., dissenting)).

87. Id.

88. See, e.g., Garfield, supra note 59, at 632 (noting that the Court uses different tests in the education and workplace contexts).

89. See id. at $642-43$.

90. See id. at $683-84$.
} 
context changes, so can the strict scrutiny test, even beyond these two neatly fashioned groups. ${ }^{91}$

Recent decisions in the circuits confirm that the Paradise test remains the controlling law when evaluating equal protection challenges to affirmative action policies aimed at promoting diversity in the workplace. ${ }^{92}$ In Dean v. City of Shreveport, appellants, two white males to whom the Shreveport Fire Department denied employment, challenged the fire department's hiring process which placed applicants into separate lists according to race and sex. ${ }^{93}$ The fire department policy, adopted to comply with a Department of Justice consent decree, required the department to have the same proportion of blacks in its department " as blacks ... bear to the appropriate work force in the particular jurisdiction." "94 Considering whether the district court wrongly granted summary judgment in favor of the City, the Fifth Circuit held that remedying past discrimination is a compelling governmental interest and that the City satisfied the first prong of the strict scrutiny test. ${ }^{95}$ The court remanded, however, for findings of whether the program was narrowly tailored. ${ }^{96}$

91. Although the circuits seem to adhere to the Wygant/Paradise construct when considering affirmative action in the workplace, recent district court decisions indicate that these courts recognize that the context of a particular challenge does drive the strict scrutiny definition. Both the District Court for the Southern District of Florida and the District Court for the Northern District of Illinois have heard equal protection challenges to minority setaside programs in the construction industry context. See Hershell Gill Consulting Engr's, Inc. v. Miami-Dade County, 333 F. Supp. 2d 1305, 1326 (S.D. Fla. 2004) (recognizing that “"[c]ontext [nevertheless] matters"” in reviewing programs that considered race and gender in awarding architectural and engineering contracts (alteration in original) (quoting Grutter v. Bollinger, 539 U.S. 306, 327 (2003))); Builders Ass'n of Greater Chicago v. City of Chicago, 298 F. Supp. 2d 725, 729-32 (N.D. Ill. 2003) (evaluating context of construction industry).

92. See, e.g., Dean v. City of Shreveport, 438 F.3d 448, 464 (5th Cir. 2006); Sherbrooke Turf, Inc. v. Minn. Dep't. of Transp., 345 F.3d 964, 971 (8th Cir. 2003).

93. $438 \mathrm{~F} .3 \mathrm{~d}$ at $452-53$.

94. Id. at 452 (quoting United States v. City of Alexandria, 614 F.2d 1358, 1368 (5th Cir. 1980)).

95. Id. at 454

96. Id. at 461. In Biondo v. City of Chicago, the fire department argued that its use of lists separating whites and minorities was an effort to comply with federal regulations that discouraged the use of standardized tests for promotions in strict sequence. 382 F.3d 680, 683 (7th Cir. 2004). The Biondo court rejected the city's argument that its policy served a compelling governmental interest, highlighting that racial quotas would be commonplace in public employment if preventing disparate impact by the use of a "minorities only" list served a compelling governmental interest. Id. at 684. The court ultimately held that the fire department's practices did not pass strict scrutiny. Id. In one of the most recent cases, Kohlbek v. City of Omaha, the Eighth Circuit held that an affirmative action plan that considered race for promotional decisions was not narrowly tailored because the use of racial classifications applied in instances where there was no identified past discrimination. 447 F.3d 552, 556 (8th Cir. 2006). Conducting the narrowly-tailored analysis, the Kohlbek court considered the following factors set forth in Paradise: "efficacy of alternative remedies, the flexibility and duration of the race-conscious remedy, the relationship of the numerical 
Relying on the strict scrutiny test as enunciated in Wygant and Paradise, the Eighth Circuit in Sherbrooke Turf, Inc. v. Minnesota Department of Transportation concluded that the Transportation Equity Act for the 21st Century ("TEA") did not violate equal protection as applied in the states of Minnesota and Nebraska. ${ }^{97}$ The plaintiffs in Sherbrooke Turf challenged the constitutionality of programs implemented under the TEA, which authorizes the use of race preferences in federally funded transportation contracts. ${ }^{98}$ The Eighth Circuit found a compelling governmental interest in ensuring that government funding was not distributed in a fashion that perpetuated the effects of discrimination in the transportation contracting industry. ${ }^{99}$ Applying the Paradise factors, the court further concluded that the programs were narrowly tailored based on the states' findings. ${ }^{100}$ As a result, the TEA, as applied, passed constitutional muster. ${ }^{101}$

The circuits seem to adopt the Grutter narrowly tailored test when evaluating affirmative action admissions policies used to create a diverse classroom environment. ${ }^{102}$ In Smith v. University of Washington, the Ninth Circuit determined the law school admissions policy at the University of Washington was narrowly tailored to achieve the compelling interest of attaining a diverse student body. ${ }^{103}$ In deciding the case, the court performed an extensive analysis of the Grutter decision, explaining that the University of Michigan Law School's admissions policy provided a template for an admissions plan that passed constitutional muster. ${ }^{104}$

goals to the relevant labor market, and the impact of the remedy on third parties." Id. at 555 (quoting Sherbrooke Turf, 345 F.3d at 971).

97. 345 F.3d at $973-74$.

98. Id. at $967-69$.

99. See id. at 969 .

100. Id. at $973-74$.

101. See id. The court, by focusing on the statistical evidence provided by the states, was particularly comfortable with the relationship between the numerical goals and the relevant labor market. Id. See also W. States Paving Co. v. Wash. State Dep't of Transp., 407 F.3d 983, 1003 (9th Cir. 2005) (finding that there was not sufficient evidence demonstrating that minorities suffer or have suffered discrimination in the Washington transportation contracting industry and concluding that the TEA as applied in the state of Washington was not narrowly tailored).

102. See, e.g., Smith v. Univ. of Wash., 392 F.3d 367, 372-75 (9th Cir. 2004).

103. Id. at 382. For the relevant years, the law school received approximately 2000 applications for 165 positions. Id. at 370 . The top 250 to 300 applicants, based on undergraduate grade point average and LSAT score, were considered "presumptive admits." Id. The remaining applicants were considered "presumptive denies." Id. Presumptive admits were reviewed by the admissions coordinator and were either admitted or referred to the admissions committee for further consideration. Id. The presumptive denies were reviewed by the assistant dean who admitted, denied, or referred applicants to an admissions committee. Id. The admissions committee ranked the top 250 to 300 candidates requiring committee referral, and the top picks were admitted. Id.

104. Id. at $372-75$. 
The plaintiffs in Smith argued that the law school's admissions policy was not narrowly tailored because (1) the admissions office supposedly sent an "ethnicity substantiation letter" to some minority applicants, ${ }^{105}$ (2) application evaluators gave Asian Americans a plus, ${ }^{106}$ and (3) a large number of white applicants were referred to the admissions committee as opposed to being admitted directly by an administrator. ${ }^{107}$ The court addressed each of these arguments and ultimately rejected them, finding that the law school's admissions program was narrowly tailored to serve the school's compelling interest in attaining a diverse student body. ${ }^{108}$

The most problematic cases concerning the "context matters" language are recent cases in the circuits that concern affirmative action admissions policies in elementary and secondary education. ${ }^{109}$ The circuits in these cases have used the "context matters" language of Grutter to justify the use of a strict scrutiny test that is distinct from the

105. The law school sent an ethnicity substantiation letter to some applicants who identified themselves as minorities on their applications. Id. at 376-77. The letter asked applicants to provide additional information on "family background (including country of origin), languages spoken, official or government status (for Native Americans), and cultural activities and associations." Id. at 377. The school argued this information was used to ascertain whether the applicant's race or ethnicity should be considered a plus factor. Id. The court held that the letter allowed the school to give preference to those minority students whose race had made a significant impact on their lives, rather than giving preference to minority students based solely on race. Id. The court concluded that the letter supported, rather than undermined, the constitutionality of the admissions program. Id.

106. The plaintiffs further argued that the school's plan was not narrowly tailored since Asian Americans were given a plus, and the school could have attracted a critical mass of Asian-American students (7-9\%) without the plus. Id. at 378. The court rejected this argument and deferred to the school's interest in achieving diversity among Asian Americans for its preeminent Asian law program. Id. The court further noted that Grutter did not establish a number or range of percentages that constituted a critical mass, and the plaintiffs did not provide any evidence that critical mass is achieved at $7-9 \%$. Id. at 379 . The court concluded the admissions policy was not unconstitutional simply because Asian Americans were given a plus. Id.

107. Id. at 370. Lastly, the plaintiffs argued that the plan was not narrowly tailored since a large number of white applicants were referred to the admissions committee rather than being directly admitted by an administrator. Id. at 380. In 1994, twenty-two minority-only applications were pulled from the discretionary group that was supposed to be sent to the admissions committee. Id. While the court said this was suspect on its face, the school provided a reasonable explanation - to make an expedited decision and actively recruit those minority students. Id. Notably, the school abandoned this practice after 1994 because it was unsuccessful. Id. The court further concluded that it was not surprising that a large number of white applicants were sent to the admissions committee rather than being directly admitted since white applicants were approximately $69-74 \%$ of total applicants. Id. at 381. Moreover, applicants sent to the admissions committee were not at a disadvantage since they received additional holistic review of their applications. Id. Thus, the law school's system of review did not establish a constitutional violation of equal protection, and the court affirmed the district court's ruling. Id. at 382.

108. Id.

109. Comfort v. Lynn Sch. Comm., 418 F.3d 1, 6 (1st Cir. 2005) (en banc), abrogated by Parents Involved in Cmty. Sch. v. Seattle Sch. Dist. No. 1, 127 S. Ct. 2738 (2007); Parents Involved VII, supra note 9, 426 F.3d at 1166; Smith, 392 F.3d at 371. 
test the Supreme Court used for evaluating affirmative action admissions policies in higher education. This dichotomy is troublesome because it suggests that courts will further splinter challenges to race-preference policies, which are currently segregated by workplace and education, into even smaller subsets in the educational arena.

In Comfort v. Lynn School Committee, the First Circuit upheld a voluntary race-preference transfer policy for elementary and secondary public schools. ${ }^{10}$ Parents of children attending public school in Lynn, Massachusetts challenged the Massachusetts Racial Imbalance Act ("RIA"), which took race into account when determining a student's ability to transfer out of a neighborhood school. ${ }^{111}$ Students were permitted to make desegregative transfers, ${ }^{112}$ but were not permitted to make segregative transfers. If a transfer request was denied, a student had the opportunity to appeal. ${ }^{113}$ Given its structure, the Lynn School District's implementation of the RIA had the possibility of resulting in the unequal treatment of students based solely on race. ${ }^{114}$

In challenging the RIA, the plaintiffs argued that the compelling governmental interest in achieving "viewpoint diversity," as recognized in Grutter, was inapplicable because Grutter was considered in the context of higher education. ${ }^{15}$ The benefits of viewpoint diversity, the plaintiffs argued, did not justify efforts to achieve racial diversity in the context of elementary and secondary education. ${ }^{116}$ The court rejected this argument, noting that there is no basis for concluding the benefits of racial diversity are limited to viewpoint diversity or that these benefits are stronger in higher education. ${ }^{117}$ The court went on to recognize that differences between $\mathrm{K}-12$ and graduate level education do not negate a compelling governmental interest in achieving diversity, but rather, that they are the "logical result of context."118 Using Grutter as an analytical

110. 418 F.3d at 6 .

111. Id. at 6-7.

112. Id. at 8. Desegregative transfers allow for a white student to transfer out of a racially isolated school and into a racially imbalanced school or for a nonwhite student to transfer out of a racially imbalanced school and into a racially isolated school. $I d$.

113. Id. Successful appeals often involved medical concerns, safety issues, or the prevention of placing siblings in separate schools. Id. Approximately half of all appeals were granted. Id.

114. Id. For example, a white student and an African-American student were assigned to the same "racially isolated" neighborhood school. Id. If both students requested a transfer to a racially imbalanced school, the white student would be allowed to transfer, and the African-American student would not be allowed to transfer. $I d$.

115. Id. at 15 ; see supra note 68 .

116. Id.

117. See id.

118. Id. at 16 ("But it is natural that safety and attendance issues will loom larger in elementary and secondary schools than in graduate schools. Conversely, lively classroom discussion is a more 
framework, the court upheld the Lynn School District's plan that implemented the RIA. ${ }^{119}$

In his concurring opinion, Judge Boudin noted that the Lynn School District's plan was substantially different from almost anything the Supreme Court had previously addressed and, therefore, that the context was different from that of the Grutter and Gratz decisions. ${ }^{120}$ The Lynn School District's plan was adopted to promote student safety and attendance, whereas the graduate school programs were adopted to promote "viewpoint diversity." 121 "[W]here the outcome in the Supreme Court is uncertain and past pronouncements were made in contexts different than the [context] now presented," he wrote, "the appellate court must exercise its own judgment on whether the local plan is constitutionally forbidden." 122 Because the "Supreme Court ha[d] not yet considered a constitutional challenge to a voluntary race-preference transfer policy for elementary and secondary schools," the Lynn court looked to Grutter and Gratz to "provide some guidance for [its] narrow tailoring inquiry into the use of race to obtain the educational benefits of diversity." "23 The court held that the Lynn School District's plan was narrowly tailored. ${ }^{124}$

\footnotetext{
central form of learning in law schools (which prefer the Socratic method) than in a K-12 setting. These differences do not negate a compelling interest in racial diversity in a $\mathrm{K}-12$ setting. Instead, they are the logical result of context.").

119. Id. at 23. Applying the strict scrutiny test, the court found a compelling governmental interest in the educational benefits of a diverse student body and that the program was narrowly tailored because it did not pursue a quota, did not "unduly harm members of any racial group," and monitored demographics for diversity in order to uphold the durational requirement mandated by Grutter. Id. at 16, 20-22.

120. See id. at 27-28 (Boudin, C.J., concurring).

121. Id. at 16 (majority opinion).

122. Id. at 28 (Boudin, C.J., concurring).

123. Id. at 17 (majority opinion).

124. Id. at 23. The court cited the plurality opinion in Paradise, where the requirements of narrow tailoring included requiring "the proponent to show that a plan or practice is (i) necessary to the declared purpose, (ii) proportional to the declared purpose, and (iii) not more burdensome than necessary on third parties." Id. at 16 (citing United States v. Paradise, 480 U.S. 149, 171 (1987)).
} 
In 2004, parents ${ }^{125}$ of students enrolled in the Jefferson County Public Schools System ("JCPS") in Jefferson County, Kentucky challenged the Jefferson County BOE Plan as violative of the Equal Protection Clause. ${ }^{126}$ In essence, the plan allowed students to choose between residential-based schools ("resides schools"), ${ }^{127}$ traditional magnet schools, ${ }^{128}$ and non-traditional magnet schools. ${ }^{129}$ JCPS originally adopted a plan in 1973 in response to the Sixth Circuit's mandate that they adopt a school board integration plan. ${ }^{130}$ The plan continued in many incarnations until June 2000 when the United States District Court for the Western District of Kentucky dissolved the

125. Plaintiff David McFarland filed on behalf of his two sons, Stephen and Daniel, who were both denied entry to traditional schools. McFarland I, supra note 5, 330 F. Supp. 2d at 837 n.3. Plaintiff Ronald Pittenger filed on behalf of his son Brandon, who was denied entry to a traditional school. Id. Plaintiff Anthony Underwood filed on behalf of his son Kenneth Maxwell Aubrey, who was denied entry to a traditional school. Id. Plaintiff Crystal Meredith filed on behalf of her son Joshua McDonald, who was unable to enroll in his resides school because it was filled to capacity. Id. He was assigned to Young school, and applied for a transfer to Bloom school, which was not in his assigned cluster. Id. He was denied admittance because it would have had an adverse effect on the racial composition of the original school he was attending. Id. The court held that the traditional school selection process was unconstitutional but that none of the plaintiffs who were denied entry to the traditional schools had proven they were injured by the race selection process. Id. at 864 . Thus, it was only Meredith, whose son was not affected by the traditional schools, who appealed. McFarland v. Jefferson County Pub. Sch., 416 F.3d 513, 514 (6th Cir. 2005), rev'd sub nom. Parents Involved in Cmty. Sch. v. Seattle Sch. Dist. No. 1, 127 S. Ct. 2738 (2007).

126. McFarland I, 330 F. Supp. $2 \mathrm{~d}$ at 836.

127. Geographic boundaries had significant impact on determining where most students would be assigned to school. Id. at 842 . "Each JCPS school, except [for] Central, duPont Manual and YPAS, Male and Butler high schools, the Brown School, Brandeis Elementary, and the traditional programs at Foster and Maupin, [had] a . . 'resides area," and based on the residence of his or her parent or guardian, each student was assigned to a "resides school." Id. The "non-magnet elementary schools were grouped into twelve clusters." Id. Each student had a designated "cluster resides schools," which included the resides school for that student. Id. The clusters were designed so that they would produce student populations within the racial guidelines. Id. There were no clusters for the non-magnet middle and high schools and each had its own resides area. Id. at 843. The only selection criteria for any student's admission to his or her resides school or a school within the cluster were age, completion of the previous grade, and residence. Id.

128. There were nine traditional magnet schools. Id. These schools "offer[ed] regular curriculum in a particular school environment" and were not considered resides schools, even though students could only apply to most of the schools based on place of residence, because all students had to apply to gain admission. $I d$.

129. There were four non-traditional magnet schools, which "offer[ed] specialized programs and curricula." Id. They did "not have a resides area," so any student was eligible to apply. Id. There were also eighteen magnet programs (small specialized programs within regular schools), as well as "optional programs in twenty-two schools" (small programs with unique attributes). Id. Resides area was not taken into account for these two programs. Id. Additionally, there were magnet career academies at the high school level that offered programs concentrated in a technical career. Id. Students were required to apply to the magnet program at these high schools. Id. Thirteen were resides schools and one was not. $I d$.

130. See Newburg Area Council, Inc. v. Bd. of Educ. of Jefferson County, 489 F.2d 925, 932 (6th Cir. 1973), vacated, 418 U.S. 918 (1974). 
desegregation decree. ${ }^{131}$ As part of the court's ruling, JCPS was ordered to stop using racial quotas and to redesign admission to its magnet schools prior to commencement of the 2002-2003 school year. ${ }^{132}$ In response to the court's order, the school board ended its use of racial quotas ${ }^{133}$ and, after considering public feedback, adopted the Jefferson County BOE Plan. ${ }^{134}$

Although the Jefferson County BOE Plan had many aspects, the part that was the subject of the equal protection challenge concerned selection for traditional schools, which admitted students by application. ${ }^{135}$ The district initially selected students for kindergarten spots in the traditional program based on place of residence and random draw lists. ${ }^{136}$ The board composed the random draw list of random applicants to the traditional school, who were "randomly sorted into four lists at each grade level: Black Male, Black Female, White Male and White Female." "Th7 "The Office of Demographics [gave] final approval on a principal's selections to ensure that the school [was] within the racial guidelines." 138

131. Hampton v. Jefferson County Bd. of Educ., 102 F. Supp. 2d 358, 381 (W.D. Ky. 2000).

132. McFarland I, 330 F. Supp. $2 \mathrm{~d}$ at 841.

133. The board stopped using quotas "at Central High School and at three magnet schools, duPont Manual High School including the Youth Performing Arts School, the Brown School, and Brandeis Elementary. Id. The board concluded that the Court's order did not include magnet traditional schools. Id.

134. Id. The stated missions of the Plan were to provide " "substantially uniform educational resources to all students' and to teach basic skills and critical thinking 'in a racially integrated environment." Id. at 842 .

135. Id. at 846. Traditional schools offered the same comprehensive curriculum as other nonmagnet schools, but they "emphasize[d] basic skills in a highly structured educational environment" and demanded strong parent involvement. Id. The traditional program was offered at certain JCPS elementary, middle, and high schools. Id. Under the complicated plan, students had the potential to choose the school they would attend at the elementary, middle, and high school levels. Id. at 84647. At the elementary and middle school levels, students were assigned a choice of schools within their "resides area," which is the geographic area in which the student's parent or guardian lives. Id. at 842-43. Each student could choose from one of several resides schools within his or her resides area. Id. at 844-45. Students had the choice of selecting a traditional or non-traditional magnet school. Id. at 843. Students who did not choose to select a school were assigned to the resides school in the student's resides area. $I d$. at 845 . Administrators, in consultation with school principals, jointly determined school assignments based on student choices, available space, and racial guidelines. $I d$. at 842 .

136. Id. at 847 .

137. Id. at 847 . Once students were selected for the traditional program in kindergarten, they were guaranteed a place in the traditional school program for each continuing year if they chose to remain in the program. $I d$. at 846 . These students became the "pipeline" for the program. $I d$. The pipeline increased each year after kindergarten through the first year of high school. Id. at 846-47. After the schools enrolled the students in the pipeline, "[t]he principal [had] discretion to draw candidates from [the] different [random draw] lists" to fill the additional available enrollment slots. Id. at 847 .

138. Id. at 847. If students were not selected for a traditional school in one year, they could 
At the outset, the district court made clear that the Jefferson County BOE Plan was subject to strict scrutiny. ${ }^{139}$ The court recognized that context matters in deciding whether JCPS identified a compelling governmental interest. ${ }^{140}$ The court concluded that, while the context of public elementary and secondary education differs from that of higher education, "the educational benefits of a diverse student body" remain the same. ${ }^{141}$ For this reason, the court measured the program against the analytical framework enunciated in Grutter and Gratz. ${ }^{142}$ In evaluating the JCPS program, however, the court observed that deference must be granted to local school boards, which act in a democratic way to preserve the essence of primary school education. ${ }^{143}$ The court ultimately concluded that the Jefferson County BOE Plan assigning students to traditional schools was unconstitutional. ${ }^{144}$ The plan was not narrowly tailored because "(1) the assignment process put[] Black and White applicants on separate assignment tracks, and (2) its use of the separate lists appear[ed] completely unnecessary to accomplish the [b]oard's goal."

Ultimately, the court held that if JCPS discontinued the portion of the plan that divided applicants to traditional schools by race, it could maintain the rest of the plan. ${ }^{146}$ Furthermore, the court found that none of the children whose parents challenged the plan were entitled to relief since "equity does not require the [p]laintiff"s children be admitted to the school of their choice in the upcoming year," and "[1]ike all other JCPS students, [the plaintiff's children could] reapply for admission to a traditional school for the [following academic year]." ${ }^{, 147}$ Plaintiff Meredith, on behalf of her daughter Crystal, appealed to the Sixth

reapply to try to join the pipeline for the following year. $I d$.

139. Id. at 848-49. The court wrote that the case was distinguishable from Grutter and Gratz, but applied strict scrutiny nonetheless. Id.

140. Id. at 849 .

141. Id. (quoting Grutter v. Bollinger, 539 U.S. 306, 328 (2003)). "The historical importance of the deference accorded to local school boards goes to the very heart of our democratic form of government. It is conceptually different-though perhaps more accepted - than the deference discussed in Grutter and Bakke." Id. at 850.

142. Id. at $856-59$.

143. See id. at 851 .

144. Id. at 864 .

145. Id. at 862 .

146. See id. at 864 .

147. Id. at 864 . Plaintiff McFarland's children were enrolled in a traditional school at the time of the ruling, making their request for injunctive relief moot. Id. Plaintiffs Pittenger and Underwood did not prove that their children were denied admission to a traditional school based solely on their race; their children had not reapplied to the traditional program. Id. 
Circuit, which issued a per curiam opinion holding that the "wellreasoned" district court opinion should stand. ${ }^{148}$

In Parents Involved in Community Schools v. Seattle School District No. 1, a nonprofit corporation called Parents Involved in Community Schools ("Parents Involved") challenged the Seattle Plan aimed at achieving diversity in the City's ten public high schools. ${ }^{149}$ The City of Seattle School District (the "District") maintained a voluntary open choice policy for its ten high schools. ${ }^{150}$ In the late 1950 s and early 1960 s, high school assignment was based solely on the student's residential neighborhood. ${ }^{151}$ Assigning students based on neighborhood resulted in de facto segregation in the schools, yielding a disproportionate mix among African-American, Asian-American, Latino, and Native American students. ${ }^{152}$

In an effort to diversify its high schools, the District allocated the available spaces in its high schools by choice. ${ }^{153}$ A majority of students chose the same five schools and when a school became oversubscribed, the District chose who would attend that school based on "a series of four tiebreakers." " which gave a ninth-grader priority to enter a school if he or she had a sibling at that school. ${ }^{155}$ The second tiebreaker, the one over which Parents Involved brought suit, was considered the race-preference tiebreaker. The race-preference tiebreaker allowed the District to select

148. McFarland v. Jefferson County Pub. Sch., 416 F.3d 513, 514 (6th Cir. 2005), rev'd sub nom. Parents Involved in Cmty. Sch. v. Seattle Sch. Dist. No. 1, 127 S. Ct. 2738 (2007).

149. Parents Involved I, supra note 5, 137 F. Supp. 2d at 1225-27.

150. Id. at 1226 .

151. Parents Involved VII, supra note 9, 426 F.3d at 1167.

152. See id. at 1166-67. "Approximately 70 percent of [Seattle] residents are white, and 30 percent are nonwhite." Id. at 1166. Seattle's public school system students "are approximately 40 percent white and 60 percent nonwhite." Id. "A majority of [Seattle's] white [public school] students live in neighborhoods north of downtown. Id. A majority of [Seattle's] nonwhite [public school] students, including approximately 84 percent of all African-American students, 74 percent of all Asian-American students, 65 percent of all Latino students, and 51 percent of all NativeAmerican students, live south of downtown." Id.

153. Id. at 1168. Because a majority of the city's nonwhite students live south of downtown, the schools located in those neighborhoods were disproportionately segregated. See id. at 1166. The District responded to this because of a historic struggle with racial isolation among its individual neighborhoods. Id. "Students . . list which high school they would like to attend in order of preference." Parents Involved I, 137 F. Supp. 2d at 1226. "Approximately $82 \%$ of students entering high school in 2000 selected one of . . f five schools as a first choice." $I d$.

154. Parents Involved VII, 426 F.3d at 1169.

155. Id. Fifteen to twenty percent of admissions to the ninth grade class were a result of the sibling tiebreaker. $I d$. 
students whose race would mitigate the imbalance in the racial makeup of the selected school. ${ }^{156}$

Parents Involved brought both state law and federal law actions in federal court. Parents Involved claimed that the racial-preference tiebreaker violated the Washington Civil Rights Act, called Initiative 200, which provides that the "state government, including local school districts, may not 'discriminate against, or grant preferential treatment to, any individual or group on the basis of race, sex, color, ethnicity, or national origin in the operation of ... public education." "157 Parents Involved also claimed that the race-preference tiebreaker violated the Equal Protection Clause of the Constitution and Title VI of the Civil Rights Act of $1964 .{ }^{158}$

The district court granted summary judgment in favor of the District on both claims. ${ }^{159}$ Parents Involved appealed, and the Ninth Circuit

156. Parents Involved I, 137 F. Supp. 2d at 1226. The District considered a school "out of balance if it deviate[d] by more than $15 \%$ from the overall racial breakdown of the population of students attending Seattle's public schools, which [was] approximately $40 \%$ white and $60 \%$ nonwhite." Id. If not for the tiebreaker preference, the school district would be de facto segregated due to residential patterns. See id. (citing the District's estimates that, without the racial tiebreaker preference, the nonwhite student populations of the 2000-2001 ninth grade class would have been $79.2 \%$; at Franklin, $30.5 \%$ at Hale, $33 \%$ at Ballard, and $41.1 \%$ at Roosevelt, and noting that, utilizing the racial tiebreaker preference, the nonwhite student populations for the 2000-2001 ninth grade class were $59.5 \%$ at Franklin, $40.6 \%$ at Hale, $54.2 \%$ at Ballard, and $55.3 \%$ at Roosevelt). Approximately 3000 students entered Seattle high schools in the 2000-2001 school year, and approximately 300 were assigned to an oversubscribed high school as a result of the racial tiebreaker preference. Parents Involved VII, 426 F.3d at 1170. In the third tiebreaker, distance between the student's home and the school was measured, calculated to within 1/100 of a mile, and the closest students were admitted first. $I d$. at 1171 . The distance tiebreaker accounted for approximately $70 \%$ to $75 \%$ of ninth grade admissions. $I d$. The fourth tiebreaker utilized a lottery system to allocate the remaining seats. Id. The lottery tiebreaker was "virtually never used" because the distance tiebreaker assigned nearly all of the students. $I d$.

157. Parents Involved I, 137 F. Supp. 2d at 1226-27 (omission in original) (quoting WASH. REV. Code ANN. § 49.60.400 (West 2006)). Washington voters passed Initiative 200 in 1998. Id. at 1227.

158. Id. at 1226 .

159. As to the state claim, the court found "a duty to construe Initiative 200 , if possible, in a way that makes the initiative consistent with state and federal constitutions." Id. at 1227 . The authority to use race to provide a "general and uniform system of public schools," interpreted by the courts to mean racially integrated schools, is an authority granted by the Washington Constitution. Id. at 1228. Application of Initiative 200 to the tiebreaker preference, therefore, would impermissibly effect an amendment to the state constitution. Id. at 1227 . The state claim was a matter of first impression since Initiative 200 had not yet been construed by the Washington Supreme Court. Id. The court had to predict how the state's highest court would apply Initiative 200. Id. (citing Comm'r v. Estate of Bosch, 387 U.S. 456, 465 (1967)). The court evaluated the federal claim under the strict scrutiny test. $I d$. at 1232 . The court found, as a matter of law, a compelling governmental interest in "[a]chieving racial diversity and mitigating the effects of de facto residential segregation." Id. at 1235. The court further held that the racial tiebreaker preference was narrowly tailored. $I d$. at 1239 . The race-preference tiebreaker only applied to schools deemed out of balance. Id. at 1238 . When the entering class of the school was balanced, the District abandoned the use of race assignments to that school "and [would] not use race to assign the remaining spaces in the school." Id. Moreover, 
invalidated the racial-preference tiebreaker as violative of Initiative 200. ${ }^{160}$ Following a subsequent tour through state and federal courts, ${ }^{161}$ the Ninth Circuit considered whether the District's use of the racepreference tiebreaker in the open choice, non-competitive high school assignment plan violated the Equal Protection Clause. ${ }^{162}$

Citing Johnson, Grutter, and Adarand, Judge Fisher, writing for the Ninth Circuit, ${ }^{163}$ concluded the policy would be upheld if the District could prove that there was a compelling governmental interest in adopting the policy and that the policy was narrowly tailored to meet that interest. ${ }^{164}$ The court noted early in the decision that " "[c]ontext matters" "165 and, therefore, defined the compelling governmental interest and determined whether the policy was narrowly tailored in a manner consistent with the education-based tests outlined by the Supreme Court in Grutter and Gratz. ${ }^{166}$

In evaluating the compelling governmental interest, the court recognized the affirmative "educational and societal benefits that flow from [racial] diversity."167 Judge Fisher wrote that these interests are similar to the interests set forth in Grutter, yet the contextual differences are significant. Grutter noted the importance in higher education to prepare students for "work and citizenship,", 168 and Judge Fisher opined that "public secondary schools have an equal if not more important role

the court found the plan sound since it utilized a "60/40 ratio as a floor, and allow[ed] a . . 15\% deviation from those numbers." Id. The court concluded that the racial tiebreaker passed strict scrutiny. Id. at 1240 .

160. Parents Involved in Cmty. Sch. v. Seattle Sch. Dist. No. 1, 285 F.3d 1236, 1253 (9th Cir. 2002), certifying questions to Washington Supreme Court, 294 F.3d 1085 (9th Cir. 2002), certified questions answered, 72 P.3d 151 (Wash. 2003), rev'd, 377 F.3d 949 (9th Cir. 2004), aff'd, 426 F.3d 1162 (9th Cir. 2005) (en banc), rev'd, 127 S. Ct. 2738 (2007).

161. See Parents Involved in Cmty. Sch. v. Seattle Sch. Dist. No. 1, 127 S. Ct. 2738, 2748-49 (2007) (reviewing procedural history).

162. Parents Involved VII, supra note 9, 426 F.3d at 1166.

163. Chief Judge Schroeder and Judges Pregerson, Hawkins, W. Fletcher, and Rawlinson joined the majority opinion. Id. Judge Kozinski concurred in the result; however, Judge Kozinski opined that the issue before the Court was "fundamentally different from almost anything that the Supreme Court has previously addressed." Id. at 1193 (Kozinski, J., concurring). Judge Bea dissented, joined by Judges Kleinfeld, Tallman, and Callahan. Id. at 1196 (Bea, J., dissenting).

164. Id. at 1166 .

165. Id. (alteration in original) (quoting Grutter v. Bollinger, 539 U.S. 306, 327 (2003).

166. Id. at 1173-92. The court would find narrow tailoring if the racial tiebreaker met the following conditions: "(1) individualized consideration of applicants; (2) the absence of quotas; (3) serious, good-faith consideration of race-neutral alternatives to the affirmative action program; (4) that no member of any racial group was unduly harmed; and (5) that the program had a sunset provision or some other end point." Id. at 1180.

167. Id. at 1173. At trial, expert testimony established the following benefits: "improved critical thinking skills," "socialization and citizenship advantages of racially diverse schools," and opportunities to network "in areas of higher education and employment." Id. at 1174-75.

168. Id. at 1175 (citing Grutter v. Bollinger, 539 U.S. 306, 331 (2003)). 
in this preparation." 169 Thus, the court found the District had a compelling governmental interest in "the educational and social benefits of racial diversity." 170 The court further found that the District's use of the race-preference tiebreaker was narrowly tailored and therefore constitutionally permissible. ${ }^{171}$

Judge Kozinski wrote a concurring opinion that challenged the wisdom of applying the Supreme Court's Grutter/Gratz strict scrutiny test to a case concerning a race-preference policy aimed at achieving diversity in secondary schools. ${ }^{172} \mathrm{He}$ analogized the Ninth Circuit's application of the Grutter/Gratz strict scrutiny test to pounding square pegs into round holes. ${ }^{173}$ In Judge Kozinski's opinion, context clearly matters, and there are meaningful differences when the government seeks racial classifications to oppress blacks or other minorities ${ }^{174}$ as opposed to teaching children how to deal respectfully and collegially with their

169. Id.

170. Id. at 1177 . The court also found a compelling governmental interest in avoiding the harms that result from racially concentrated schools. Id. at 1179 .

171. Id. at 1180-92. The court first considered the individualized evaluation of each applicant. Id. at 1180 . The court found that this prong of the test was not totally relevant in the current context because there was no competition issue, unlike Grutter and Gratz. Id. More importantly, because race itself is the relevant consideration when addressing de facto segregation, the tiebreaker preference "must necessarily focus on the race of its students." Id. at 1183 (citing Comfort v. Lynn Sch. Comm., 418 F.3d 1, 18 (1st Cir. 2005) (en banc), abrogated by Parents Involved in Cmty. Sch. v. Seattle Sch. Dist. No. 1, 127 S. Ct. 2738 (2007)). For these reasons, according to the court, a district need not conduct an individualized consideration of each student since a noncompetitive, voluntary plan is otherwise narrowly tailored. $I d$. at 1183.

The court then turned to the absence of quotas and found that the " 15 percent plus or minus variance is not a quota because it does not reserve a fixed number of slots for students based on race." Id. at 1184. The District sought to enroll a critical mass of white/nonwhite students in its oversubscribed schools to reach its compelling interests. Id. at 1185. The fifteen percent plus/minus variance was a goal rather than a rigid ratio. See id. at 1186 (stating that the variance was a "flexible measurement"). The court found that the tiebreaker policy was necessary and the most race-neutral alternative since the tiebreaker preference allowed the realization of the compelling interests and discouraged a return to enrollment patterns based on racially segregated housing patterns. Id. at 1187. Here, as in Grutter, the court deferred to the District's judgment in evaluating race-neutral alternatives. Id. at 1188 .

Concerning the fourth prong, the court found that the policy did not create undue harm because "(1) the District is entitled to assign all students to any of its schools, (2) no student is entitled to attend any specific school and (3) the tiebreaker does not uniformly benefit any race or group of individuals to the detriment of another." Id. at 1192. Finally, the court had no issue with the sunset provision that the Supreme Court, in Grutter, found essential to the viability of any race-preference policy. Id. In this instance, the District reviewed the plan annually and was responsive to choice patterns and constituents' concerns. Id. The court shared Justice O'Connor's hope that in twentyfive years, "the use of racial preferences will no longer be necessary." Id. (quoting Grutter v. Bollinger, 539 U.S. 306, 343 (2003)).

172. See id. at 1193-96.

173. See id. at 1193 .

174. Id. 
peers during their formative years. ${ }^{175}$ Further, he wrote that the Supreme Court's strict scrutiny tests have been more reactive than proactive, changing definitional course in response to the context of each issue presented. ${ }^{176}$ For these reasons, Judge Kozinski believed the Seattle Plan should have been evaluated under a rational basis standard of review. Specifically, he would have employed a "robust and realistic rational basis review ... where courts consider the actual reasons for the plan in light of the real-world circumstances that gave rise to it." ${ }^{\text {"177 }}$ Judge Kozinski concluded that the Seattle Plan was " far from the original evils at which the Fourteenth Amendment was addressed." "178 Rather, it gave "the American melting pot a healthy stir" without benefiting any group. ${ }^{179}$ For this reason, Judge Kozinski would have left the decision to those in charge, namely local officials, and affirmed the decision of the district court.

Judge Bea, joined by three other judges, wrote a strong dissent. ${ }^{180}$ Judge Bea rejected the Grutter Court's definition of a compelling governmental interest, writing that the case is not about the right to be educated in a racially diverse academic setting. ${ }^{181}$ Rather, according to Judge Bea, the issue was whether the government can impose on students the decision to be educated in a diverse setting. ${ }^{182}$ According to Judge Bea, the District's plan was nothing more than racial balancing, based on quotas, and must therefore be struck down. ${ }^{183}$ Judge Bea essentially

175. Id. at 1194.

176. See id. at 1195 (stating that "the Supreme Court's opinions are necessarily forged by the cases presented to it"). Comparing this case to past Supreme Court decisions, Judge Kozinski noted that "the Seattle plan carrie[d] none of the baggage the Supreme Court has found objectionable in cases where it has applied strict scrutiny." Id. at 1194. Unlike modern affirmative action, the Plan did not "give one racial group an edge over another." Id. at 1193. "[T] he plan [did] not segregate persons by race" or "involve racial quotas." Id. "These are meaningful differences." Id.

177. Id. at 1194 (citation omitted) (citing City of Cleburne v. Cleburne Living Ctr., 473 U.S. 432 (1985)); see Cleburne, 473 U.S. at 446 (holding that the "State may not rely on a classification whose relationship to an asserted goal is so attenuated as to render the distinction arbitrary or irrational").

178. Id. at 1195 (quoting Comfort v. Lynn Sch. Comm., 418 F.3d 1, 29 (1st Cir. 2005) (Boudin, C.J., concurring), abrogated by Parents Involved in Cmty. Sch. v. Seattle Sch. Dist. No. 1, 127 S. Ct. $2738(2007))$.

179. Id. at 1196.

180. See id. at 1196-1222 (Bea, J., dissenting).

181. Id. at 1196. ("At the outset, it is important to note what this case is not about. The idea that children will gain social, civic, and perhaps educational skills by attending schools with a proportion of students of other ethnicities and races, which proportion reflects the world in which they will move, is a notion grounded in common sense. It may be generally, if not universally, accepted. But that is not the issue here.").

182. Id.

183. Id. at 1202-03. Judge Bea opined that the Grutter diversity interest pursued "genuine diversity" in the student body, where race was considered as a single plus factor among many 
accused the Ninth Circuit of gerrymandering the strict scrutiny test to fit its desired goal. ${ }^{184} \mathrm{He}$ argued the court's reliance on Grutter was inappropriate because, in that case, the Supreme Court recognized that there were a host of factors, race being one, which a candidate for admission to the law school can bring to a classroom. ${ }^{185}$ In contrast, the Seattle Plan merely focused on race, and focused on race in a large context, not an individual context. ${ }^{186}$ Ultimately, Judge Bea agreed with Judge Kozinski that context matters, and wrote that the Grutter case was limited in its precedential weight to decisions concerning challenges to affirmative action admissions programs in higher education. ${ }^{187}$

The circuit court judges in Comfort, Meredith, and Parents Involved disagreed as to how courts should treat the use of race-preference student assignment plans. Their disparate opinions likely prompted the Court to grant certiorari in Meredith and Parents Involved. Unfortunately, the resulting Supreme Court decision was as fractionalized as the opinions of the First, Sixth, and Ninth Circuits.

factors. Id. at 1202 . Here, the District pursued a diversity interest which considered only racial diversity, specifically a predefined grouping of races in the schools. Id. at 1202-03. The District's interest was not a valid compelling interest, and violated equal protection. Id.

184. See id. at 1197 (arguing that the majority applied a "watered-down standard of review ... improperly labeled 'strict scrutiny"'). Judge Bea stated that the majority and concurring opinions "trie[d] to distinguish past Supreme Court cases ... by focusing on the effects of the discrimination rather than the fact of the discrimination." $I d$. at 1198. This allowed the majority and concurring opinions to create two categories distinguishing the Seattle Plan: "(1) the effects of other race discrimination plans were much worse than Seattle's and (2) the effects were visited on certain races." Id. Judge Bea concluded, however, that these differences were irrelevant because "[t]here is no de minimis exception to the Equal Protection Clause." Id. (quoting Monterey Mech. Co. v. Wilson, 125 F.3d 702, 712 (9th Cir. 1997)). Additionally, equal protection protects the rights of individuals, "not the rights of certain races or groups." Id. Judge Bea further wrote that not calling the Seattle Plan a quota does not make it something other than a quota- "the numerical quota is the percentage by which the school in question's racial composition differs from the school district's target." Id.

185. Id. at 1202.

186. Id.

187. Id. at 1207. "The 'academic freedom' of a university allows it 'to determine for itself on academic grounds who may teach, what may be taught, how it shall be taught, and who may be admitted to study." Id. (quoting Regents of the Univ. of Cal. v. Bakke, 438 U.S. 265, 312 (1978)). High schools do not have these freedoms. Id. High schools are not permitted to decide who may teach based upon racial grounds. Id. High schools may not decide who "may be admitted to study." Id. When the government provides public education in secondary schools, it " must be made available to all on equal terms."” Id. (quoting Plyler v. Doe, 457 U.S. 202, 223 (1982)). Additionally, there are no U.S. Supreme Court cases providing high schools with the same "academic freedoms" afforded to universities by the First Amendment. Id. (citing United States v. Fordice, 505 U.S. 717, 728-29 (1992)). 


\section{THE SUPREME COURT's DECISION IN PARENTS INVOLVED}

On June 28, 2007 the Court issued a joint decision in the Meredith and Parents Involved cases. ${ }^{188}$ Justice Roberts, writing for a divided Court, acknowledged the need to evaluate the cases under strict scrutiny since "racial classifications are simply too pernicious to permit any but the most exact connection between justification and classification.", 189 He then identified the two recognized interests that the Court has found compelling enough to justify intrusion on an individual's right to equal protection under the law. ${ }^{190}$

Of the interest in remedying present effects of past discrimination, Justice Roberts wrote that continued use of race beyond that justified by a court-ordered recognition of segregation is not permissible. ${ }^{191}$ Since each school program was voluntary in nature, the Court found that neither program served the compelling governmental interest of remedying present effects of past discrimination.

Of the interest in attaining a diverse student body, Justice Roberts wrote, "[t]he present cases are not governed by Grutter," and achieving diversity in the classroom is limited to "the unique context of higher education." 192 In other words, the Court found that neither program could serve the compelling governmental interest of attaining a diverse student body that the Grutter and Gratz opinions, which considered diversity at the undergraduate and law school levels, announced. ${ }^{193}$

Justice Kennedy agreed with four of his brethren that the racepreference school assignment plans as drafted could not withstand constitutional muster. ${ }^{194}$ However, he wrote, the fact " $[\mathrm{t}]$ hat the school districts consider these plans to be necessary should remind us our highest aspirations are yet unfulfilled."195 To Justice Kennedy, it appears, diversity in public school education is a compelling governmental interest that school districts remain free to achieve. ${ }^{196}$

\footnotetext{
188. Parents Involved in Cmty. Sch. v. Seattle Sch. Dist. No. 1, 127 S. Ct. 2738 (2007).

189. Id. at 2752 (quoting Gratz v. Bollinger, 539 U.S. 244, 270 (2003)).

190. Id. at $2752-53$.

191. See id. at 2752 ("Any continued use of race must be justified on some other basis.").

192. Id. at 2754. A four-Justice plurality rejected the compelling governmental interests put forth by the school boards as nothing more than racial balancing, which, according to the plurality, is not constitutionally permissible. See id. at 2755-59.

193. Id. at 2754 .

194. Id. at 2788 (Kennedy, J., concurring).

195. Id.

196. See id. at 2789 ("Diversity, depending on its meaning and definition, is a compelling educational goal a school district may pursue.").
} 
The four Justices dissenting from the majority's opinion advocated that the Court adopt a third compelling governmental interest in ensuring racial balancing in the classroom. ${ }^{197}$ Justice Breyer wrote that, absent support for the types of race-preference programs under the Court's consideration, American education could revert back to its pre-Brown $v$. Board of Education days. ${ }^{198}$

The language of the Parents Involved opinion, and the slim majority by which it was decided, falls short of prohibiting future expansion of the Court's existing limitation on what constitutes a compelling governmental interest for using race as a consideration. However, the Court's failure to create a new compelling governmental interest, and its unwillingness to fit public education within the confines of viewpoint diversity, confirm the concerns Justice Ginsburg expressed during the Meredith hearings. The Parents Involved decision constitutionally prohibits what was once constitutionally required. ${ }^{199}$

Nevertheless, the Court's reluctance to extend the compelling governmental interest in attaining viewpoint diversity to include classrooms at every educational level did not necessarily preclude it from upholding race-preference student assignment plans. The Court's previously articulated view that "context matters" in evaluating the compelling need for a particular program could have supported a third compelling governmental interest. In this particular instance, the matter concerned the ability of school boards to retain programs as a means to prevent a return to de facto segregation in public schools.

\section{A CALl to CREATE A NeW COMPELling GovernMental INTEREST IN PREVENTING A RETURN TO DE FACTO SEGREGATION}

Justice Kennedy and the dissenting Justices in Parents Involved advocated that race-preference student assignment plans at the $\mathrm{K}-12$ level are essential to promoting the societal goal of equality. ${ }^{200}$ These

\footnotetext{
197. See id. at 2820-21 (Breyer, J., dissenting). Justice Breyer described this interest as one aimed at "promoting or preserving greater racial integration of public schools." Id. at 2820 . He noted that the interest possesses three essential elements: 1) the historical and remedial element of rectifying consequences of prior segregation; 2) the educational element of "overcoming the adverse educational effects produced by and associated with highly segregated schools;" and 3) the democratic element of producing "an educational environment that reflects 'the pluralistic society' in which our children will live.” Id. at 2820-21 (quoting Swann v. Charlotte-Mecklenburg Bd. of Educ., 402 U.S. 1, 16 (1971)).

198. Id. at 2837.

199. See Liptak, supra note 2.

200. See supra notes $195-98$ and accompanying text.
} 
plans are essential to ensuring fairness and equality in education, to exposing future leaders to differing viewpoints, and to protecting the spirit and the goals of the civil rights movements. Legally, however, their constitutional durability is questionable, particularly after the Supreme Court refused to fit race-preference student assignment plans into the Court's two previously articulated compelling governmental interests.

\section{A. The Court's Rejection of Race-Preference Student Assignment Plans Under the Strict Scrutiny Test}

The body of affirmative action case law prior to Parents Involved left little room to uphold the race-preference school assignment plans at issue. As a general rule, race-preference policies only survive strict scrutiny if the defending party can show that the policy is necessary to remedy present effects of past discrimination, or if it has adopted a mission statement or other policy statement that explains that the purpose of the program is to achieve "viewpoint diversity" and that the program considers students individually to assure differing views. Today, few school districts suffer from the effects of past discrimination and, as a result, would not easily meet the first compelling governmental interest standard. The same schools would likely fail to establish that their programs are aimed at attaining viewpoint diversity since these programs generally fail to consider students individually when making classroom assignments.

The Parents Involved plurality found the Jefferson County BOE Plan fatally flawed. ${ }^{201}$ Because the program had its genesis in a court-ordered mandate, it could have only been upheld if the Court found that present effects of past discrimination remained in Jefferson County. ${ }^{202}$ Courts have found that court-ordered consent decrees, ${ }^{203}$ congressional, state, or city-council findings, ${ }^{204}$ or any other substantiated statistics or other

\footnotetext{
201. See supra note 191-93 and accompanying text.

202. See supra note 191 and accompanying text.

203. See United States v. Paradise, 480 U.S. 149, 164 (1987).

204. See, e.g., City of Richmond v. J.A. Croson Co., 488 U.S. 469, 484 (1989) ("The majority [at the circuit court level] found that national findings of discrimination in the construction industry, when considered in conjunction with the statistical study concerning the awarding of prime contracts in Richmond, rendered the city council's conclusion that low minority participation in city contracts was due to past discrimination 'reasonable."'). But see id. at 504 ("While the States and their subdivisions may take remedial action when they possess evidence that their own spending practices are exacerbating a pattern of prior discrimination, they must identify that discrimination, public or private, with some specificity before they may use race-conscious relief. Congress has made national findings that there has been societal discrimination in a host of fields. If all a state or local
} 
evidentiary indicia are sufficient evidence of the present effects of past discrimination. ${ }^{205}$ The proof, however, must be specific and narrowly tailored to the remedial program it seeks to justify. ${ }^{206}$ Thus, in Croson, when the City of Richmond provided only a generalized assertion that there had been past discrimination in the entire construction industry, the Court found it was too broad to support a compelling governmental interest in requiring prime contractors awarded city construction contracts to subcontract at least thirty percent of the dollar amount of each contract to one or more MBEs. ${ }^{207}$ In Paradise, the Court held that a court order was justified by finding a compelling governmental interest in a race-preference promotion plan. ${ }^{208}$

Jefferson County originally adopted its court-ordered desegregation plan in response to a Sixth Circuit directive, called the Haycraft desegregation decree. ${ }^{209}$ In June 1999, the same court found that the Haycraft plan was still legally in effect. ${ }^{210}$ The following year, however, the court dissolved the desegregation decree and ordered JCPS to cease using racial quotas and to redesign and reevaluate admissions procedures at the grammar schools. ${ }^{211}$ The plan that the Supreme Court reviewed was a voluntary extension of the court's desegregation plan. ${ }^{212}$

The Seattle Plan, which Parents Involved challenged, was adopted in response to an identified imbalance in school registration and the racial tension that resulted. ${ }^{213}$ In fact, the Seattle Plan was the first comprehensive desegregation plan adopted by a major city "voluntarily without a court order."214 The Sixth Circuit had already concluded that

government need do is find a congressional report on the subject to enact a set-aside program, the constraints of the Equal Protection Clause will, in effect, have been rendered a nullity.").

205. See Croson, 488 U.S. at 501; Paradise, 480 U.S. at 172-74.

206. See Croson, 488 U.S. at 493 ("The test also ensures that the means chosen 'fit' this compelling goal so closely that there is little or no possibility that the motive for the classification was illegitimate racial prejudice or stereotype."); Paradise, 480 U.S. at 183-84 ("[T]he... requirement imposed in this case does not disproportionately harm the interests, or unnecessarily trammel the rights, of innocent individuals.").

207. Croson, 488 U.S. at $510-11$.

208. Paradise, 480 U.S. at $185-86$. The Supreme Court held that a fifty percent promotion requirement was permissible under the Equal Protection Clause in that it was justified by a compelling governmental interest in eradicating discriminatory exclusion of blacks from positions and was narrowly tailored to serve its purposes. $I d$.

209. Newburg Area Council, Inc. v. Bd. of Educ., 489 F.2d 925, 932 (6th Cir. 1973), vacated, 418 U.S. 918 (1974).

210. Hampton v. Jefferson County Bd. of Educ., 72 F. Supp. 2d 753, 774 (W.D. Ky. 1999).

211. Hampton v. Jefferson County Bd. of Educ., 102 F. Supp. 2d 358, 377-81 (W.D. Ky. 2000).

212. See Parents Involved in Cmty. Sch. v. Seattle Sch. Dist. No. 1, 127 S. Ct. 2738, 2749 (2007).

213. Id. at $2746-48$.

214. Parents Involved VII, supra note 9, 426 F.3d at 1168. 
there is no longer a need to legally mandate desegregation or any program that would promote integration in public schools. ${ }^{215}$ Despite Seattle's long running voluntarily imposed desegregation program, the city had never provided credible evidence of present effects of past discrimination. $^{216}$ Consequently, the Court was unable to find a compelling governmental interest based on a historic need to right past vestiges of segregation. $^{217}$

The Court was equally unwilling to find that the Seattle Plan or Jefferson County BOE Plan was designed to attain the type of viewpoint diversity that the Court previously upheld. Justice Powell, writing for a fractionalized majority in Bakke, was the first to recognize a compelling governmental interest in assuring diverse voices in the classroom. ${ }^{218}$ In Grutter, Justice O'Connor wrote, "today we endorse Justice Powell's view that student body diversity is a compelling state interest that can justify the use of race in university admissions." ${ }^{219}$ For this reason, the Court in Grutter found that the Law School's mission statement to admit a "critical mass" of underrepresented minority students was essential to its educational mission. ${ }^{220}$ Evidence of a mission statement that highlights a program's goal of attaining diversity for its educational benefits is sufficient to support a compelling governmental interest. ${ }^{221}$

The benefits of viewpoint diversity in primary and secondary school classrooms are distinguishable from those in higher education. To the extent that undergraduate and graduate schools are engaged in training future leaders, there is a significant value in those leaders understanding contrary viewpoints. ${ }^{222}$ These viewpoints may bring "experiences,

215. See McFarland I, supra note 5, 330 F. Supp. 2d at 851 (quoting Deal v. Cincinnati Bd. of Educ., 369 F.2d 55, 61 (6th Cir. 1966) (discussing the active role of democratically elected school boards in promoting diversity and the court's deference toward their decisions).

216. The dissent in the Ninth Circuit's 2005 decision pointed out that both parties conceded that the Plan did not attempt to remedy past effects of discrimination in the school district or community. Parents Involved VII, 426 F.3d at 1197 (Bea, J., dissenting). At the district court level, it was established that the Seattle Plan was created for the sole purpose of "mitigat[ing] the historical effects on its high schools of the residential segregation of Seattle's neighborhoods, and to allow all students the opportunity to benefit from the pedagogical and socio-cultural values a racially diverse school offers." Parents Involved I, supra note 5, 137 F. Supp. 2d at 1233. The District Court concluded that convincing evidence was presented that segregated housing patterns existed in the Seattle School District which caused the school systems to be racially concentrated. Id. at 1235 .

217. See Parents Involved, 127 S. Ct. at 2752.

218. Regents of the Univ. of Cal. v. Bakke, 438 U.S. 265, 311-12 (1978).

219. Grutter v. Bollinger, 539 U.S. 306, 325 (2003).

220. See id. at 333,340 .

221. See id.; see also Garfield, supra note 73, at 45-46 (discussing the role of the Law School's mission statement).

222. Cf. Sweatt v. Painter, 339 U.S. 629, 633-34 (1950) (concluding that an education at a "Texas State University for Negroes" would not be substantially similar to that received at the 
outlooks, and ideas that enrich the training of [a] student body and better equip ... graduates to render with understanding their vital service to humanity." 223 Creating diversity in the classroom is equally important to civil tolerance. $^{224}$ The Court has also recognized that diversity in college and post-graduate classrooms " "better prepares students for an increasingly diverse workforce and society, and better prepares them as professionals." $" 225$

The proponents of the Seattle Plan and the Jefferson County BOE Plan were unable to produce specific evidence that their plans were created to ensure the benefits of viewpoint diversity. ${ }^{226}$ Both plans were designed to provide learning opportunities at the best schools in the district for students who might not have had the opportunity to attend those schools if the school districts were drawn along neighborhood lines. ${ }^{227}$ Because the missions of the Jefferson County BOE Plan and Seattle Plan did not state a goal of enhancing the learning experience of all in the classroom, the notion of viewpoint diversity was never likely to support either under the strict scrutiny test.

The plurality's decision that the educational benefits of a diverse classroom are not the same at varying levels of education not only supported its ultimate conclusion that the plans did not survive the strict scrutiny test, it also served to resolve a conflict among the lower courts. Prior to Parents Involved, several appellate court judges voiced their disagreement about appropriate application of Justice Powell's findings in Bakke to $\mathrm{K}-12$ programs. $^{228}$ In concurring and dissenting opinions, respectively, Judges Kozinski and Bea suggested that, while viewpoint

University of Texas Law School). In Sweatt, the Court made a similar point with specific reference to legal education:

The law school, the proving ground for legal learning and practice, cannot be effective in isolation from the individuals and institutions with which the law interacts. Few students and no one who has practiced law would choose to study in an academic vacuum, removed from the interplay of ideas and the exchange of views with which the law is concerned.

Id. at 634 .

223. Bakke, 438 U.S. at 314.

224. See Grutter, 539 U.S. at 330 (noting that diversity within the student body helps students understand individuals of different races and assists in eliminating racial stereotypes).

225. Id. (quoting Brief for Amici Curiae at 3).

226. See Parents Involved in Cmty. Sch. v. Seattle Sch. Dist. No. 1, 127 S. Ct. 2738, 2753-54 (2007) (discussing the inapplicability of viewpoint diversity as a compelling interest to the plans).

227. See Parents Involved VII, supra note 9, 426 F.3d at 1167-69; McFarland I, supra note 5, 330 F. Supp. $2 d$ at 842.

228. The Court granted certiorari in Grutter to "resolve the disagreement among the Courts of Appeals on a question of national importance: Whether diversity is a compelling interest that can justify the narrowly tailored use of race in selecting applicants for admission to public universities." Grutter v. Bollinger, 539 U.S. 306, 322 (2003). 
diversity was a sufficient compelling governmental interest, there was no demonstrable evidence of the need for viewpoint diversity in the cases before them. ${ }^{229}$ Judge Boudin wrote that the context of a plan adopted to promote safety and student attendance was so distinct from anything the Court had previously considered that it was wrong of the Comfort majority to apply the Court's previously stated compelling governmental interests in the case before him. ${ }^{230}$ To Judge Kozinski, applying Grutter to the case before him was tantamount to pounding square pegs into round holes. ${ }^{231}$ Judge Bea, joined by three other judges, wrote that it was wholly inappropriate to consider the Seattle Plan in the same context as public higher education programs. ${ }^{232}$ The Supreme Court's decision in Parents Involved resolved a split among the circuits regarding the applicability of viewpoint diversity in challenges to race-preference programs in the context of primary and secondary school education.

Neither the District nor the Jefferson County Board of Education were able to present evidence that their programs remedied present effects of past discrimination and, for this reason, five justices found that both programs failed strict scrutiny. ${ }^{233}$ These cases, however, presented an issue of race-preference in a context wholly different from anything the Court had previously considered. Although the challenged cases arose in the educational arena, they presented the Court the first instance in which a remedial goal's own success rendered it unconstitutional. The Court failed in considering the challenged race-preference student assignment plans in a different context, and in recognizing the importance of assuring that states or their agencies are afforded the ability to preserve their achieved goal of racial integration.

\section{B. A Compelling Governmental Interest in Preserving Achieved Goals of Racial Integration}

The plurality's reasoning was flawed for its failure to recognize that the challenged programs presented a context different from those previously considered by the Court. Evaluating the school board plans in light of their goal of achieving desegregation should have prompted the Court to articulate a third compelling governmental interest: ensuring

229. Parents Involved VII, 426 F.3d at 1194 (Kozinski, J., concurring); id. at 1203-04 (Bea, J., dissenting).

230. See supra notes $121-23$ and accompanying text.

231. See supra notes $172-79$ and accompanying text.

232. See supra notes $180-87$ and accompanying text.

233. See supra notes $189-94$ and accompanying text. 
that states retain goal-oriented programs, even if those programs have achieved their stated goals, when eliminating the program would result in a return to the very problem the program initially sought to redress.

The Court's standard for creating compelling governmental interests supports adopting an interest in preserving programs whose abolishment threatens a return to the de facto segregation the program originally sought to cure. In determining whether a particular program meets the compelling governmental interest test, courts must evaluate "the sincerity of the reasons advanced by the governmental decision makers." 234 In this instance, Justices of the Supreme Court ${ }^{235}$ presidents of elite academic institutions ${ }^{236}$ and social commentators ${ }^{237}$ have all expressed a belief that the absence of race-preference programs in academia — at any level—will result in a return to the disproportionately white classrooms of the $1950 \mathrm{~s}$ and 1960s. A recent study by the Civil Rights Project at Harvard University found that as "desegregation plans have been dismantled across the South ... the proportion of black students in majority white schools has decreased by 13 percentage points." ${ }^{238}$ Several other studies confirm an increase in residential isolation among racial groups. ${ }^{239}$

234. See supra note 76 and accompanying text.

235. See supra notes 2,11 and accompanying text.

236. See Heather Mac Donald, Elites to Anti-Affirmative-Action Voters: Drop Dead, CiTY J., Winter 2007, at 15, 29, available at http://www.city-journal.org/html/17_1_prop209.html (quoting response of the president of the University of Michigan to the Michigan vote to ban racial preference: "II am standing here today to tell you that I will not allow this university to go down the path of mediocrity."').

237. See, e.g., Charles R. Calleros, Law, Policy, and Strategies for Affirmative Action in Higher Education, 43 CAL. W. L. REV. 151, 156-69 (2006) (providing a guide for university admissions policy and strategy); Kevin R. Johnson \& Angela Onwuachi-Willig, Cry Me a River: The Limits of "A Systemic Analysis of Affirmative Action in American Law Schools," 7 AFR.-AM. L. \& POL'Y ReP. 1, 26 (2005) (criticizing Richard H. Sander's article concluding that affirmative action programs harm minority law students); Jeffrey Rosen, How I Learned to Love Quotas, N.Y. TIMES MAG., June 1,2003 , at 52, 52-55 (defending affirmative action). For an interesting discussion on the compatibility and efficacy of the non-legal social movement and legal movement supporting affirmative action, in the context of the Grutter case, see Tomiko Brown-Nagin, Elites, Social Movements, and the Law: The Case of Affirmative Action, 105 Colum. L. REV. 1436 (2005) (reasoning that the affirmative action movement only achieved minimal gains through legal means, as evidenced by the Grutter decision).

238. Erica Frankenberg et al., The Civil Rights Project, Harvard Univ., A Multiracial Society with Segregated Schools: ARE We Losing the Dream? 37 (2003); see also Jonathan Kozol, Still Separate, Still Unequal: America's Educational Apartheid, HARPER's MAG., Sept. 2005, at 41, 41 (noting that "schools around the country that had been integrated either voluntarily or by force of law have since been rapidly resegregating" and providing statistics).

239. See, e.g., Lawrence Hardy, Separate but Unequal: A New Study Documents a Return to Segregation, AM. SCH. BOARD J., Sept. 2001, at 10, 10 (citing 2001 Civil Rights Project report finding that "desegregation-era gains are slipping away"); James Traub, Return to Segregation, N.Y. TIMES MAG., Dec. 9, 2001, at 91, 91 (noting that the 2000 census report confirms that Hispanics and Asians are living in more heavily Hispanic and Asian neighborhoods than they were ten years ago, while whites and blacks are only slightly more exposed to one another than they were in 1990). 
The District adopted the Seattle Plan because assigning students to schools based on neighborhood residence resulted in de facto segregation. ${ }^{240}$ The same was true of the Lynn School Board, whose plan was challenged in the Comfort decision, and the Jefferson County Board of Education. ${ }^{241}$ In both instances, the school board was driven by the need to achieve the constitutional guarantees of Brown v. Board of Education, which held that segregation in public schools is "inherently unequal." ${ }^{242}$ Justice Kennedy, in his concurrence, noted that abolishment of these programs may result in a return to neighborhood assignment plans, which may, in turn, yield de facto segregation again. ${ }^{243}$ Given these circumstances, the Court would have best served the needs of school districts to retain the hard-earned gains of equal education at the $\mathrm{K}-12$ level by finding a compelling governmental interest in assuring that programs created in response to de facto segregation remain constitutional once they attain their goal of integration.

There was ample evidence available to support the assertion that abolishment of race-preference student assignment plans would result in a return to de facto segregation. Neighborhood school assignment plans remain the most race-neutral means of assigning students to particular schools at the $\mathrm{K}-12$ level. ${ }^{244}$ It is also the means by which most schools assign students. ${ }^{245}$ The flaw in neighborhood assignment plans, however, is that to date, many neighborhoods remain racially segregated. ${ }^{246}$ Thus, assignment by neighborhood would result in segregated schooling.

The Court has long recognized that Americans live in segregated areas and that housing patterns require congressional and judicial intervention in order to assure racial equity. Congress enacted the Voting Rights Act to "prevent discrimination in the exercise of the electoral franchise and to foster our transformation to a society that is no

\footnotetext{
240. See supra notes $149-56$ and accompanying text.

241. See supra notes $110-14,134-38$ and accompanying text.

242. 347 U.S. 483, 495 (1954).

243. See Parents Involved in Cmty. Sch. v. Seattle Sch. Dist. No. 1, 127 S. Ct. 2738, 2797 (2007) (Kennedy, J., concurring) (noting that "neighborhoods in our communities do not reflect the diversity of our Nation as a whole" and calling for creative solutions to bring students from different backgrounds together).

244. See James E. Ryan \& Michael Heise, The Political Economy of School Choice, 111 YALE L.J. 2043, 2050 (2002) (recognizing that physical boundaries yielded segregated schooling); see also Kevin S. Huffman, Charter Schools, Equal Protection Litigation, and the New School Reform Movement, 73 N.Y.U. L. REv. 1290, 1290 (1998) (noting that neighborhood school assignments were most common to public schools).

245. Huffman, supra note 244.

246. Kirstin Downey, Segregation Persists in Housing, Study Says, WASH. Post, Apr. 6, 2005, at E2; Cathy Keen, Housing Segregation Persists in Many Parts of the Nation, Study Shows, May 6, 2004, http://news.ufl.edu/2004/05/06/neighborhood-desegregation/.
} 
longer fixated on race." 247 One purpose of the Act was to "insure that [States'] devices ... would not be used to thwart the will of Congress to secure the franchise for blacks" 448 such as racial "gerrymandering," which is "[t]he practice of dividing a geographical area into electoral districts, often of highly irregular shape, to give one political party an unfair advantage by diluting the opposition's voting strength." 249 State legislatures would draw boundaries by neighborhood, extending lines so that particular groups would be included together. Implicit in this guard against racial gerrymandering is that racial groups tend to live in neighborhoods that are segregated from other racial groups. Since evidence supports that current segregated housing patterns remain the norm, school assignment plans based on living patterns would yield de facto segregation.

The school boards in the Meredith and Parents Involved cases could have met the burden of showing that their race-preference student assignment plans were adopted in response to concern about the potential for de facto segregation - that abolishment of their programs would result in a return to the very evil their plans sought to cure. When the Jefferson County Board of Education presented its case to the district court, it put forth evidence that the Jefferson County BOE Plan was developed as a means to retain the gains it had made through its courtordered desegregation plan. ${ }^{250}$ After the district court ruled that racial quotas were no longer necessary to achieve equal education, the Jefferson County Board of Education held public hearings and devised a means to ensure its desegregation efforts would not be thwarted. ${ }^{251}$ Similarly, the District presented evidence that the Seattle Plan was created because high school assignment based solely on a student's residential neighborhood resulted in de facto segregation. ${ }^{252}$ In each instance, the school boards would have been able to show that their plans were necessary to support the compelling governmental interest in preserving the realized educational mandate of integrated schooling that the Court first set forth in Brown.

\footnotetext{
247. Georgia v. Ashcroft, 539 U.S. 461, 490 (2003).

248. S. REP. No. 97-417, at 6 (1982), reprinted in 1982 U.S.C.C.A.N. 177, 182.

249. BLACK's LAW DiCTIONARY 708 (8th ed. 2004).

250. See supra notes $134-38$ and accompanying text.

251. Id.

252. See supra notes $153-56$ and accompanying text.
} 
This third compelling governmental interest - ensuring that gains made through use of race-preference plans will not be undone-is appropriate in light of the need to maintain the strides toward equality made over the past four decades. This interest is better suited for consideration of student assignment plans at the $\mathrm{K}-12$ level than is the interest of "viewpoint diversity." At the outset, the race-preference student assignment plans were not created to ensure students hear from different voices in the classroom. ${ }^{253}$ They were created to guarantee that all students receive the same quality of education. ${ }^{254}$ The need for diversity in the elementary classroom is mandated by the understanding that there is a link between desegregated schools and academic achievement. $^{255}$ The driving notion of access to equal education is wholly different from hearing diverse viewpoints. For this reason, it is appropriate to consider what constitutes a compelling governmental interest in programs aimed at grades $\mathrm{K}-12$ in a context different from programs for institutions of higher learning.

Carving out a new compelling governmental interest would be problematic in some respects. First, it would require the Court to expand its definition of permissible compelling governmental interests in order to ensure the viability of programs created in response to a particular problem. Second, it might send a message to lower courts that resultoriented jurisprudence is preferable in the area of affirmative action law, suggesting to lower courts permission to fashion their own definitions of what supports a compelling governmental interest.

Opponents may argue that there is no reason to create a contextual divide between race-preference policies in graduate schools and those in $\mathrm{K}-12$ programs. Justice Breyer, in his dissent, found that viewpoint diversity is helpful to students in public grammar and high schools. ${ }^{256}$ In Grutter, the Court found that the educational benefits diversity was designed to produce were substantial, including promoting cross-racial understanding, breaking down racial stereotypes, enabling students to better understand persons of different races, promoting learning outcomes, better preparing students for an increasingly diverse

253. See supra notes $226-27$ and accompanying text.

254. Id.

255. See Gary Orfield, The Civil Rights Project, Harvard Univ., Schools More SEPARATE: CONSEQUENCES OF A DECADE OF RESEGREGATION, 9-10 (July 2001), available at http://www.civilrightsproject.ucla.edu/research/deseg/Schools_More_Separate.pdf; see also Brown v. Board of Educ., 347 U.S. 483, 494-95 (1954) (noting that segregation deprives children of benefits they would receive in an integrated classroom).

256. See Parents Involved in Cmty. Sch. v. Seattle Sch. Dist. No. 1, 127 S. Ct. 2738, 2822-23 (2007) (Breyer, J., dissenting). 
workforce and society, and better preparing students to become professionals. $^{257}$ These benefits should be realized equally by grade school children and those attending graduate school.

The Court reaffirmed its commitment to letting the context of a particular program drive a court's evaluation as recently as $2005 .^{258}$ On a macro level, the race-preference student assignment plans should have been considered in the context of assuring the success of remedial racepreference programs. This argument in favor of distinguishing the context of diversity in grade schools is the most compelling, and therefore suggests that the Court should have considered plans that admit students to various elementary and secondary schools in a context distinct from plans that admit students to institutions of higher education.

\section{CONCLUSION}

According to five Justices, the Court has already defined a compelling governmental interest that justifies race-preference student assignment plans-achieving viewpoint diversity. ${ }^{259}$ According to the Court, there is educational value in achieving viewpoint diversity in the classroom. However, since the race-preference student assignment plans challenged in Parents Involved did not survive strict scrutiny under this compelling governmental interest, the Court should have enunciated a new compelling governmental interest to avoid striking down racepreference student assignment plans at the $\mathrm{K}-12$ level.

It would have been perfectly appropriate, and indeed justifiable, for the Court to have found a compelling governmental interest in preserving programs whose abolishment threatens a return to the de facto segregation the programs originally sought to cure. Under this test, a court could uphold a race-preference plan if the defending party showed that invalidating the plan would result in a return to the segregation or racial discrimination that existed before the government put the program in place. Unfortunately, the concern Justices Breyer and Ginsburg voiced at the Meredith hearings seems to have fallen on the deaf ears of a majority of the Court. ${ }^{260}$

The Parents Involved decision poses a potential threat of extinction to programs that secure educational equality to students in particular

257. Grutter v. Bollinger, 539 U.S. 308, 330 (2003).

258. See supra note 78 and accompanying text.

259. See supra notes $196-98$ and accompanying text.

260. See supra notes 2,11 and accompanying text. 
districts. Studies show that reliance on neighborhood student assignment plans is likely to result in de facto segregation. For this reason, the Court should recognize that educational programs at the elementary and secondary school levels should be considered in a different context than programs at institutions of higher learning, thereby allowing the Court to define a compelling governmental interest for this new context. A contextual approach to evaluating the constitutionality of race-preference programs allows the Court to tailor its decision-making process to ensure that the goal of remaining a racially integrated society is fully achieved.

"Interpretation is a chameleon that takes its color from its context...."261 Where race-preference plans or programs are concerned, the Court has recognized that the context of a program can drive the result. In this instance, the Court would have been well advised to interpret the context of race-preference programs for grades $\mathrm{K}-12$ as something wholly separate from affirmative action programs at the graduate level. Doing so might have resulted in a continuation of the strides toward a color-blind society that school districts across the country have fought so hard to achieve. 